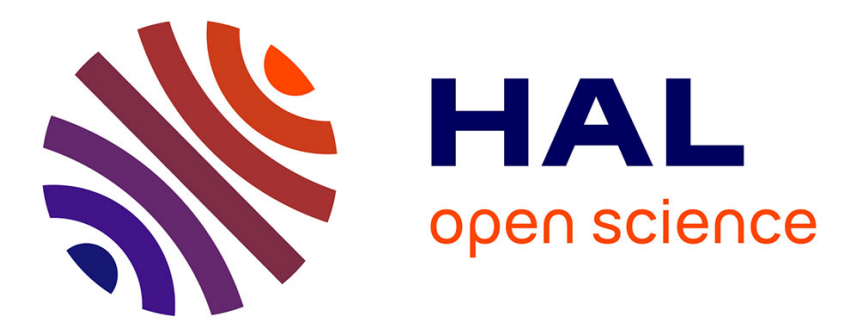

\title{
Product Diversification in the European Banking Industry: Risk and Loan Pricing Implications
}

Laetitia Lepetit, Emmanuelle Nys, Philippe Rous, Amine Tarazi

\section{To cite this version:}

Laetitia Lepetit, Emmanuelle Nys, Philippe Rous, Amine Tarazi. Product Diversification in the European Banking Industry: Risk and Loan Pricing Implications. 2005. hal-00918399

\section{HAL Id: hal-00918399 \\ https://hal-unilim.archives-ouvertes.fr/hal-00918399}

Preprint submitted on 13 Dec 2013

HAL is a multi-disciplinary open access archive for the deposit and dissemination of scientific research documents, whether they are published or not. The documents may come from teaching and research institutions in France or abroad, or from public or private research centers.
L'archive ouverte pluridisciplinaire HAL, est destinée au dépôt et à la diffusion de documents scientifiques de niveau recherche, publiés ou non, émanant des établissements d'enseignement et de recherche français ou étrangers, des laboratoires publics ou privés. 


\title{
Product diversification in the European banking industry: Risk and loan pricing implications
}

\author{
Laetitia Lepetit, Emmanuelle Nys, Philippe Rous, Amine Tarazi* \\ Université de Limoges, LAPE, 5 rue Félix Eboué, 87031 Limoges Cedex, France
}

March 2006

\begin{abstract}
The purpose of this paper is to investigate the relationship between bank risk and product diversification in the changing structure of the European banking industry. Based on a broad set of European banks for the period 1996-2002, our study shows that banks expanding into non-interest income activities present higher risk than banks which mainly supply loans. Whereas previous studies (mainly on U.S. banks) focused on portfolio diversification effects we explore risk implications of cross-selling determinants of loan pricing as an alternative explanation. Our results show that higher income from other activities is associated with lower lending rates which suggests that banks may actually use loans as a loss leader altering default screening and monitoring activities and consequently risk pricing.
\end{abstract}

\section{JEL classification: G21}

Keywords: bank risk, interest income, non-interest income, product diversification

\section{Introduction}

In the context of financial deregulation that took place in the seventies and in the eighties, western banking systems faced major changes in the form of increased competition, concentration and restructuring. Banks have reacted to the new environment by adopting a proactive strategy widening the range of products they offer to their clients. These changes mainly implied an increasing share of non-interest income in profits. Non-interest income stems from traditional service charges (checking, cash management, letters of credit...) but

\footnotetext{
*Corresponding authors: Tel: +33-555-43-69-32, emmanuelle.nys@unilim.fr (E. Nys); laetitia.lepetit@unilim.fr (L. Lepetit); philippe.rous@unilim.fr (P. Rous); amine.tarazi@unilim.fr (A. Tarazi).
} 
also from new sources. The decline in interest margins induced by higher competition lead banks to charge higher fees on existing or new services (cash withdrawal, bank account management, data processing...). As a result, the structure of bank income experienced a dramatic change in both the U.S. and Europe. In the eighties, non-interest income represented 19 percent of U.S. commercial banks' total income. This share had grown to 43 percent of total income in 2001 (Stiroh, 2004). In Europe, non-interest income has increased from 26 percent to 41 percent between 1989 and 1998 (ECB, 2000).

Since the adoption of the new universal banking principle, commercial banks can compete on a wider range of market segments (investment banking, market trading ...). Numerous studies questioned the risk implications of this new environment on bank risk. The issue is of importance for the safety and soundness of the banking system and a major challenge for supervisory authorities. Among others, U.S. regulators, such as Dingell (2002), have raised questions about the pricing of loans, claiming that "commercials banks may be winning high service fees by underpricing credit facilities as a loss leader to their clients".

The existing literature, mostly based on U.S. banks, either focused on portfolio diversification effects (risk return profile) (Boyd et al., 1980; Kwan, 1998; De Young and Roland, 2001) or on incentives approaches (Rajan, 1991; John et al., 1994; Puri, 1996; Boyd et al., 1998). Few studies were able to show that the combination of lending and non-interest income activities allows for diversification benefits and therefore risk reduction. Conversely, some papers find a significant positive impact of diversification on earnings volatility (De Young and Roland, 2001; Stiroh, 2004; Stiroh and Rumble, 2006). As noted by De Young and Roland (2001), three main reasons may explain this increase in risk. Firstly, income from lending activities is likely to be relatively stable over time because switching and information costs make it costly for either borrowers or lenders to walk away from a lending relationship. In contrast, income from non-interest income activities may suffer from larger fluctuations as it might be easier to switch banks for this type of activities than for lending. Secondly, expanding non-interest income activities may imply a rise in fixed costs (for example, additional staff may be required), which increases the operational leverage of banks. Conversely, once a lending relationship is established, the marginal cost induced by the supply of additional loans is limited to interest expenses. Thirdly, because bank regulators do not require banks to hold capital against non-interest income activities, earnings volatility may increase because of a higher degree of financial leverage. Moreover, as mentioned by Stiroh (2004), cross-selling of different products to a core customer does not imply diversification 
benefits (more products are sold to the same customer) which may explain why interest income growth and non-interest income growth are highly correlated in his study.

The aim of this paper is to assess the risk implications of the changing structure of the European banking industry which has shifted away from traditional intermediation activities (deposit funded loans) towards activities generating non-interest income. Using individual bank data from 1996 to 2002 for 951 European banks, we start by analysing the link between bank risk and the degree of output diversification measured by three indicators: the income share i/ of non-interest income, ii/ of trading income and iii/ of commissions and fees income. We hence start by comparing the risk level of banks which have expanded into non traditional activities with banks which have not pursued such a strategy. While previous work on bank diversification was essentially dedicated to the U.S. banking industry and limited to the overall link between risk and diversification (diversification benefits) we specifically focus on the determinants of loan rates. In this sense our aim is also to explore whether banks engaged in diversification actually underprice loans using them as a loss leader in order to capture clients to whom they may sell non-interest income products (Dingell, 2002; Nys, 2003).

The remainder of the paper is organized as follows. Section 2 reviews the literature on bank risk and product diversification and shows how our study extends the existing work. Section 3 analyses the relationship between the changing structure of bank income and risk in the European banking industry. Section 4 presents the methodology and the results of our investigation of cross-selling between lending and non traditional activities. Concluding remarks are presented in the final section.

\section{Existing literature}

Over the two past decades, the combination of traditional and non traditional activities in banking has given rise to a substantial number of studies. Most of the existing literature is dedicated to potential diversification benefits for banks to engage in a broader scope of activities. In general, these studies, which essentially considered U.S. data, provide mixed results. For instance, Boyd et al. (1980), who simulated portfolios of banking and non-bank subsidiaries during the 1970s, find a potential for risk reduction at relatively low levels of non-bank activities. The results obtained by Kwast (1989) to determine an optimal riskminimising combination of banking and non-banking activities for the period 1976-1985 show only a slight potential for risk reduction. Gallo et al. (1996) find, over the 1987-1994 
period, that combining bank and mutual fund activities allows for some diversification benefits increasing profitability for moderated risk levels ${ }^{1}$.

Another strand of the literature reports no diversification benefits or even an increase in risk when combining traditional and non interest income activities. According to Boyd and Graham (1986), expansion by BHCs into non-bank activities during the seventies tended to increase the risk of failure of banks during the less stringent policy period. Demsetz and Strahan (1997) who study the stock returns of BHCs between 1980 and 1993 find that although banks extended their product mixes, no risk reduction could be observed as banks tended to move to riskier activities and to lower their capital ratio. Kwan (1998) who investigated bank section 20 subsidiaries during the 1990-1997 period underlines the increased volatility of accounting returns despite a non increase in bank profitability. DeYoung and Roland (2001) look at the impact of fee-based activities on bank profitability and volatility for large U.S. commercial banks from 1988 to 1995 . They conclude that feebased activities, which represent a growing share of banking activities, increase the volatility of bank revenue. Stiroh (2004) who assesses the potential benefit of diversification for US banks engaging in non interest activities for the period 1984-2001, shows that net interest income and non interest income (which is relatively more volatile) are increasingly correlated (lower diversification benefits). Stiroh and Rumble (2006) find similar results while considering the US financial holding companies for the period 1997-2002.

Several causes were explored to explain why diversification benefits were not effective in some studies. DeYoung and Roland (2001) suggest three explanations: high competition on non-interest income activities, fixed costs associated to fee-based activities and lack of regulation on non-interest income activities. According to Stiroh (2004) and Stiroh and Rumble (2006), as mentioned above, higher correlation between non-interest income and interest income can be due to possible cross-selling of different products to the same customer.

This paper extends the earlier work on bank diversification in several directions. First, to our knowledge, this is the first study to examine the case of the European banking industry which experienced tremendous changes over the last decade ${ }^{2}$. Second, this study considers a

\footnotetext{
${ }^{1}$ Another group of studies simulate mergers between bank holding companies and nonbank financial firms (Boyd and Graham, 1988; Boyd et al., 1993; Saunders and Walter, 1994; Laderman, 1999; Lown et al. 2000; Allen and Jagtiani, 2000; for a survey, see Kwan and Laderman, 1999). Simulations were ran to assess the impact on risk of combining traditional banking activities and securities and/or insurance activities (US commercial banks were not allowed to provide such activities before 1999).

${ }^{2}$ Acharya, Hasan and Saunders (2002) have studied the case of Italian banks by looking at the degree of diversification of the loan portfolio. Their findings show that loan diversification is not guaranteed to produce a
} 
large set of risk measures based on accounting data but also on market data and analyses the correlation between shifts in risk and changes in the degree of product diversification at the bank individual level. Third, this is the first paper which empirically raises the issue of loan pricing implications of the trend towards product diversification by assuming potentials for cross-selling among traditional and non-traditional activities which could induce banks to lower lending rates and underprice credit risk.

\section{Bank risk and product diversification}

\subsection{Data set}

We use a sample consisting of an unbalanced panel of annual report data from 1996 to 2002 for a set of European banks established in 14 European countries: Austria, Belgium, Denmark, France, Germany, Greece, Italy, Netherlands, Norway, Portugal, Spain, Sweden, Switzerland, United Kingdom (see Appendix, Table A.1). The bank data used for the estimates come from Bankscope Fitch IBCA ${ }^{3}$. Considering the 2129 banks reported in Bankscope we restricted our sample to 951 banks. First, we deleted all the banks with less than three years of time series observations. Second, in order to minimize the effects of measurement errors we have excluded all the outliers by eliminating the extreme bank/year observations (2.5\% lowest values and $2.5 \%$ highest values) for each considered variable. Based on the clean sample of 951 banks we also consider a sub-sample of listed banks. Market data (bank stock prices) come from Datastream International. Banks with discontinuously traded stocks being omitted, 156 banks remain in this sub-sample.

Descriptive statistics of our two samples are presented in Table 1. Both samples show sufficient heterogeneity in different types of banking activities, enabling us to analyse the behaviour of banks depending on their degree of diversification.

\subsection{Degree of diversification and risk}

The literature cited above highlights, with regards to U.S. banks, that activity diversification does not necessarily imply lower risk, and may on the contrary increase bank risk. As a first step we check if similar results can also be obtained for European banks. One

higher return and/or lower risk for banks. Another study (Smith, Staikouras and Wood, 2003) dedicated to European banks focused on the correlation between non-interest income and interest income and their variability showing that the increased importance of non-interest income stabilised profits in the banking industry during the period 1994-1998.

${ }^{3}$ All the banks in our sample publish their annual financial statements at the end of the calendar year. 
way to capture the degree of diversification of bank activities in the literature (see Stiroh (2004)) is to consider the structure of income statements that is the shares of net interest income generated by traditional activities and non-interest income produced by non traditional activities. We therefore split our samples into different panels of banks on the basis of the value of the ratio of net non interest income to net operating income (NNII) ${ }^{4}$. We consider as diversified, banks for which the value of the NNII ratio is higher than the third quartile $\left(\mathrm{Q}_{75}\right)$ and as non diversified, banks with a NNII ratio lower than the first quartile $\left(\mathrm{Q}_{25}\right)$.

Five standard measures of risk, based on accounting data and determined for each bank throughout the period, are used to compare the level of risk of these two groups of banks: (i) the standard deviation of the return on average assets (SDROA); (ii) the standard deviation of the return on average equity (SDROE); (iii) the coefficient of variation of the return on average assets (CVROA); (iv) the coefficient of variation of the return on average equity (CVROE); (v) the ratio of loan loss provisions to net loans (LLP).

We also compute insolvency risk measures: (i) the "Z-score" (ADZ) ${ }^{5}$ which indicates the probability of failure of a given bank; (ii) the "ZP-score" (ADZP) as in Goyeau and Tarazi (1992) and its two additive components ${ }^{6}$ which we call $\mathrm{ADZP}_{1}$ and $\mathrm{ADZP}_{2} . \mathrm{ADZP}_{1}$ is a measure of bank portfolio risk whereas $\mathrm{ADZP}_{2}$ is a measure of leverage risk.

Our product diversification measure is also disaggregated, as in De Young and Roland (2001) and in Stiroh (2004), to allow for deeper insights. Considering our data, we distinguish two components of non-interest income: commission and fee income and trading income. Firstly, we compare the level of risk of banks which are characterized by high levels of feebased activities that is banks with a ratio of net commission income to net operating income (COM) higher than the third quartile $\mathrm{Q}_{75}$, with banks with the same ratio not exceeding the value of the first quartile (COM lower than $\left.\mathrm{Q}_{25}\right)$. Secondly, we undertake the same comparison on the basis of the degree of reliance on trading activities (ratio of net trading income to net operating income (TRAD) higher than $\mathrm{Q}_{75}$ versus TRAD lower than $\mathrm{Q}_{25}{ }^{7}$ ).

\footnotetext{
${ }^{4}$ Net non-interest income is defined as the difference between non-interest income and non-interest expenses; net operating income is the sum of net interest income and net non interest income.

${ }^{5} \mathrm{ADZ}=(1+$ average ROE $) / \mathrm{SDROE}$ where ROE and SDROE are expressed in percentage. The Z-score is the number of standard deviations that profits must fall to drive a firm into bankruptcy. Higher values of Z-scores imply lower probabilities of failure (see Boyd and Graham (1986) for details).

${ }^{6} \mathrm{ADZP}=\mathrm{ADZP}_{1}+\mathrm{ADZP}_{2}=\frac{\text { average ROA }}{\mathrm{SDROA}}+\frac{\text { average EQUITY }}{\mathrm{SDROA}}$.

${ }^{7}$ Net commission income $=$ commission income - commission expense; net trading income $=$ trading income trading expense.
} 
Table 1. Descriptive statistics for European commercial and cooperative banks, on average over the period 1996-2002 (\%)

\begin{tabular}{|c|c|c|c|c|c|c|c|c|c|c|c|c|c|c|}
\hline & LOANS & DEP & EQUITY & LLP & EXPENSES & $\mathrm{ROA}$ & ROE & MARGIN & $\begin{array}{l}\text { Interest } \\
\text { revenue }\end{array}$ & $\begin{array}{l}\text { Lending } \\
\text { rate }\end{array}$ & NII & NNII & $\mathrm{COM}$ & TRAD \\
\hline \multicolumn{15}{|c|}{ Sample 1 : Non listed and listed banks (951 banks) } \\
\hline Mean & 58.03 & 56.88 & 9.94 & 0.69 & 1.71 & 0.878 & 8.79 & 2.73 & 6.37 & 7.63 & 62.46 & 35.13 & 25.52 & 6.29 \\
\hline Std & 19.36 & 19.56 & 8.51 & 0.77 & 1.94 & 1.814 & 9.96 & 1.80 & 2.90 & 3.75 & 24.37 & 25.21 & 18.44 & 11.03 \\
\hline Max & 97.94 & 93.99 & 59.70 & 9.28 & 46.59 & 30.01 & 77.25 & 18.54 & 37.31 & 33.26 & 100.00 & 100.00 & 89.66 & 94.67 \\
\hline Min & 4.52 & 0.30 & 0.26 & -2.23 & 0.00 & -24.87 & -79.49 & -7.62 & 0.05 & 0.00 & -137.07 & -191.56 & -34.50 & -84.99 \\
\hline \multicolumn{15}{|c|}{ Sample 2 : Listed banks (156 banks) } \\
\hline Mean & 64.36 & 59.15 & 8.95 & 0.79 & 2.06 & 1.10 & 11.04 & 3.45 & 7.07 & 7.26 & 66.51 & 33.25 & 26.41 & 5.54 \\
\hline Std & 13.83 & 16.88 & 5.77 & 0.66 & 3.58 & 1.66 & 7.19 & 1.76 & 2.87 & 2.73 & 15.66 & 16.33 & 20.57 & 8.06 \\
\hline Max & 92.12 & 90.96 & 55.00 & 8.00 & 46.59 & 23.53 & 75.77 & 17.63 & 37.31 & 20.31 & 97.09 & 97.22 & 100 & 55.55 \\
\hline Min & 26.58 & 12.92 & 2.23 & -0.54 & 0.26 & -1.74 & -34.89 & 0.22 & 1.97 & 0.00 & 2.78 & -89.55 & 0 & -0.54 \\
\hline
\end{tabular}

Variable definitions (all variables are expressed in percentage): LOANS = loans/total assets; DEP = deposits/total assets; EQUITY = equity/total assets; LLP = loan loss provisions/net loans; EXPENSES = personnel expenses/total assets; $R O A=$ return on average assets; ROE = return on average equity; NII = net interest income/net operating income; $C O M=$ net commission income/net operating income; TRAD = net trading income/net operating income; NNII = net non interest income/ net operating income; MARGIN = net interest income/total earning assets; Interest revenue = Interest revenue/total earning assets; Lending rate $=$ Interest on loans/net loans. 
The results in Table 2 show that banks which exhibit high degrees of diversification display higher risk and insolvency measures ${ }^{8}$. Therefore, on the whole, our results obtained for European banks are in line with those underlined for U.S. banks by DeYoung and Roland (2001) and Stiroh (2004). When we focus on the different sources of non traditional income our results also show that greater reliance on fee-based activities is associated with higher risk and higher default (insolvency) risk whereas higher dependence on trading activities does not necessarily imply higher risk levels.

To check for robustness, we compute risk and insolvency measures using market data for our sample of listed banks. Three additional risk measures are used which are the standard deviation of daily stock returns (SDRET), the market model beta coefficient estimated through a single factor model (BETA) and specific risk (RSPEC) which is the standard deviation of the market model residual. Insolvency risk (bank default risk) is captured using a market data based Z-score ${ }^{9}$ (MDZ) and the distance to default ${ }^{10}$ (DD). The results obtained in table 3 confirm those obtained with accounting data ${ }^{11}$.

To explore the determinants of risk we extend our study by analysing throughout our sample period shifts in bank risk depending on diversification trends.

\footnotetext{
${ }^{8}$ Similar results, reinforced with higher significance levels, are obtained when the median or the mean is used to discriminate our two sets of banks.

${ }^{9}$ MDZ-score $=\frac{\overline{\mathrm{R}}+1}{\sigma}$, where $\overline{\mathrm{R}}$ and $\sigma$ are respectively the mean and the standard deviation of the daily returns $R_{t}$ for a given year.

${ }^{10}$ The distance to default is inferred from the market value of a risky debt (Merton, 1977) based on the Black and Scholes (1973) option pricing formula.

${ }^{11}$ Banks were also ranked on the one hand depending on their average level of diversification and on the other hand given their average risk level over the period 1996-2002. A Spearman test was conducted to compare their respective ranks in each set. The null hypothesis of independency of each group of banks was rejected . In other words, banks with a higher level of risk are also those exhibiting a higher level of diversification (see Tables A2 and $\mathrm{A} 3$ in appendix).
} 
Table 2. Product diversification and accounting indicators of risk for European banks (1996-2002)

\begin{tabular}{|c|c|c|c|c|c|c|c|c|c|}
\hline & \multicolumn{5}{|c|}{ Risk Measures } & \multicolumn{4}{|c|}{ Insolvency risk measures } \\
\hline & SDROA & SDROE & CVROA & CVROE & 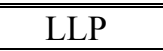 & ADZ & ADZP & ADZP1 & ADZP2 \\
\hline \multicolumn{10}{|l|}{$N N I I>Q_{75}$} \\
\hline Mean & 1.155 & 8.959 & 0.616 & -0.562 & 2.191 & 30.385 & 28.874 & 2.160 & 26.714 \\
\hline (Obs.) & 237 & 237 & 237 & 237 & 214 & 237 & 237 & 237 & 237 \\
\hline \multicolumn{10}{|l|}{$N N I I<Q_{25}$} \\
\hline Mean & 0.521 & 5.273 & 1.085 & 0.940 & 0.494 & 49.587 & 47.823 & 3.050 & 44.772 \\
\hline (Obs.) & 237 & 237 & 237 & 237 & 228 & 237 & 237 & 237 & 237 \\
\hline $\begin{array}{l}\text { T-statistic of } \\
\text { the mean Test }\end{array}$ & $5.148^{* * *}$ & $3.427 * * *$ & -1.194 & -2.181 & $2.630 * * *$ & $-5.171 * * *$ & $-5.300 * * *$ & $-3.608 * * *$ & $-5.315 * * *$ \\
\hline \multicolumn{10}{|l|}{$C O M>Q_{75}$} \\
\hline Mean & 1.095 & 8.568 & 0.502 & -0.170 & 1.648 & 31.902 & 31.387 & 2.299 & 29.088 \\
\hline (Obs.) & 234 & 234 & 234 & 234 & 216 & 234 & 234 & 234 & 234 \\
\hline \multicolumn{10}{|l|}{$C O M<Q_{25}$} \\
\hline Mean & 0.688 & 6.046 & 0.763 & 1.012 & 0.857 & 44.763 & 44.692 & 2.984 & 41.708 \\
\hline (Obs.) & 234 & 234 & 234 & 234 & 224 & 234 & 234 & 234 & 234 \\
\hline $\begin{array}{l}\text { T-statistic of } \\
\text { the mean Test }\end{array}$ & $2.268 * * *$ & $2.429 * * *$ & -0.602 & -2.254 & $1.345^{*}$ & $-4.401 * * *$ & $-3.645^{* * *}$ & $-2.663 * * *$ & $-3.644 * * *$ \\
\hline \multicolumn{10}{|l|}{$T R A D>Q_{75}$} \\
\hline Mean & 1.197 & 8.353 & 0.878 & 0.061 & 2.369 & 28.540 & 27.578 & 2.213 & 25.365 \\
\hline (Obs.) & 177 & 177 & 177 & 177 & 166 & 177 & 177 & 177 & 177 \\
\hline \multicolumn{10}{|l|}{ TRAD $<Q_{25}$} \\
\hline Mean & 0.597 & 8.064 & 0.689 & 0.208 & 0.262 & 49.146 & 44.208 & 3.557 & 40.651 \\
\hline (Obs.) & 177 & 177 & 177 & 177 & 166 & 177 & 177 & 177 & 177 \\
\hline $\begin{array}{l}\text { T-statistic of } \\
\text { the mean Test }\end{array}$ & $3.369 * * *$ & 0.159 & 0.316 & -0.191 & $2.775 * * *$ & $-5.383 * * *$ & $-4.697 * * *$ & $-4.172 * * *$ & $-4.629 * * *$ \\
\hline
\end{tabular}

T statistics test for the null:"Risk/Insolvency is not higher for high level of product diversification".

$* * *, * *$ and * indicate significance respectively at the $1 \%, 5 \%$ and $10 \%$ levels for a unilateral test.

Variable definitions: NNII = ratio of net non interest income to net operating income; COM = ratio of net commission income to net operating income; TRAD = ratio of net trading income to net operating income; SDROA = standard deviation of the return on average assets; SDROE = standard deviation of the return on average equity; $C V R O A=$ coefficient of variation of the return on average assets; CVROE = coefficient of variation of the return on average equity; LLP = ratio of loan loss provisions to net loans; $A D Z=Z$-score; $A D Z P=$ "ZP-score"; $A D Z P_{1}=$ measure of bank portfolio risk; $A D Z P_{2}=$ measure of leverage risk. 
Table 3. Product diversification and market indicators of risk for European listed banks (1996-2002)

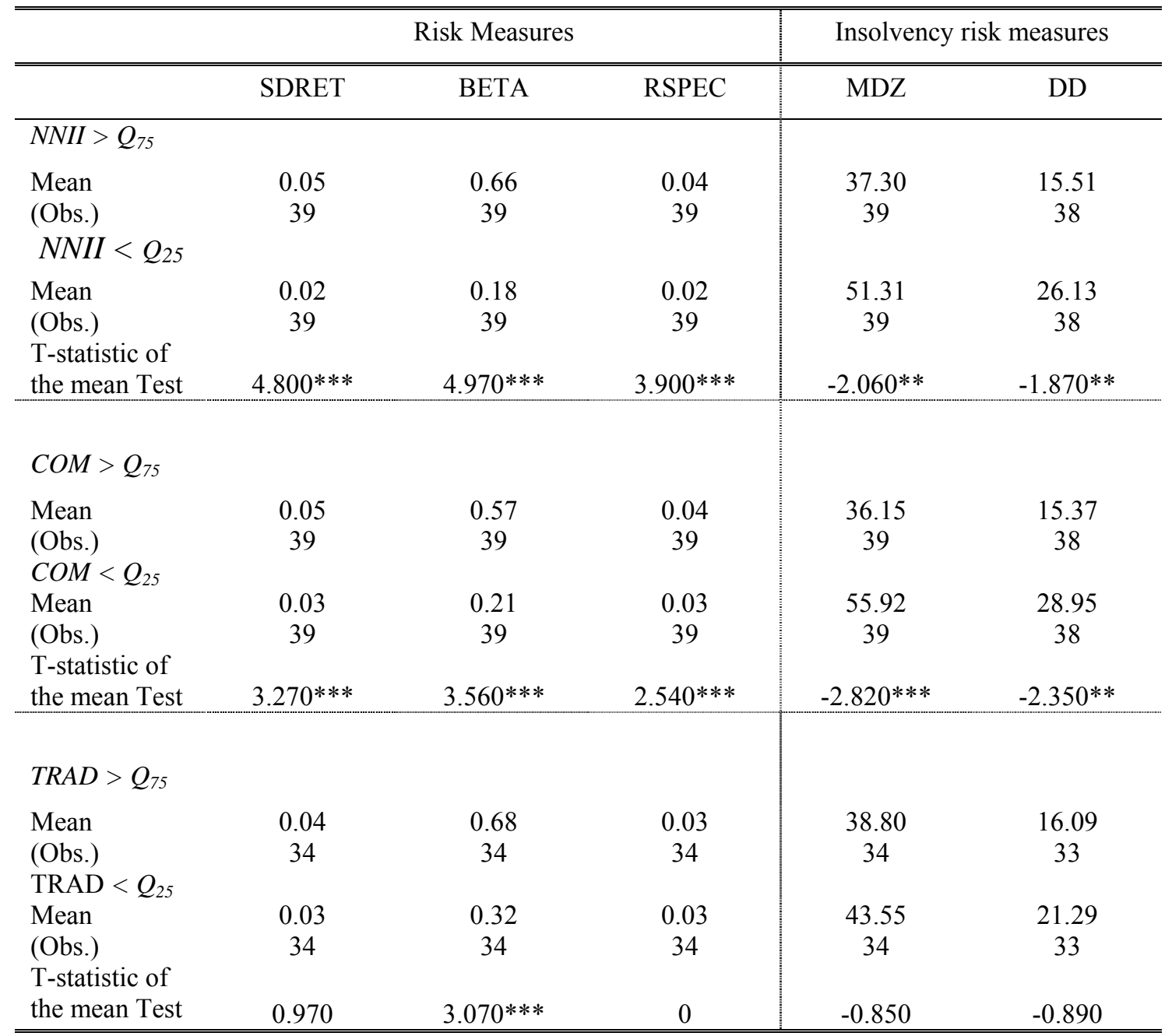

T statistics test for the null:"Risk/Insolvency is not higher for high level of product diversification". ***, ** and * indicate significance respectively at the $1 \%, 5 \%$ and $10 \%$ levels for a unilateral test. Variable definitions: NNII = ratio of net non interest income to net operating income; $C O M=$ ratio of net commission income to net operating income; TRAD = ratio of net trading income to net operating income; SDRET = standard deviation of daily stock returns; $B E T A=$ market model beta; $R S P E C=$ standard deviation of the market model residual; $M D Z=$ market data based Z-score; $D D=$ distance to default.

\subsection{Trends in diversification and risk shifts}

To study the link between the shift towards non interest income and bank risk we consider high frequency data (market data) therefore restricting our analysis to the sample of listed banks. In a first series of tests we investigate if banks experiencing a relatively high annual growth rate in non traditional activities $(\Delta \mathrm{NNII}>3 \%$ per year) exhibit a higher 
increase in risk than banks with a relatively low annual growth rate of NNII $(\Delta \mathrm{NNII}<1 \%$ per year $)^{12}$. A similar procedure is applied for the two components of net non interest income.

Table 4. Growth rates of degree of diversification and risk for European listed banks (19962002)

\begin{tabular}{|c|c|c|c|c|c|}
\hline & \multicolumn{3}{|c|}{ Growth rate of risk Measures } & \multicolumn{2}{|c|}{ Growth rate of insolvency risk measures } \\
\hline & $\triangle$ SDRET & $\triangle \mathrm{BETA}$ & $\triangle \mathrm{RSPEC}$ & $\Delta \mathrm{MDZ}$ & $\Delta \mathrm{DD}$ \\
\hline$\Delta N N I I>3 \%$ & & & & & \\
\hline $\begin{array}{l}\text { Mean } \\
\text { (Obs.) } \\
\Delta N N I<1 \%\end{array}$ & $\begin{array}{c}13.28 \\
45\end{array}$ & $\begin{array}{c}196.70 \\
45\end{array}$ & $\begin{array}{c}11.28 \\
45\end{array}$ & $\begin{array}{c}26.10 \\
45\end{array}$ & $\begin{array}{c}-6.57 \\
37\end{array}$ \\
\hline $\begin{array}{l}\text { Mean } \\
\text { (Obs.) } \\
\text { T-statistic of } \\
\text { the mean Test }\end{array}$ & $\begin{array}{c}15.55 \\
36 \\
-3.560 \\
\end{array}$ & $\begin{array}{c}31.87 \\
36 \\
4.880 * * *\end{array}$ & $\begin{array}{c}12.93 \\
36 \\
-2.680 \\
\end{array}$ & $\begin{array}{c}21.93 \\
36 \\
6.230 * * *\end{array}$ & $\begin{array}{c}-4.51 \\
30 \\
-0.840 \\
\end{array}$ \\
\hline$\Delta C O M>3 \%$ & & & & & \\
\hline $\begin{array}{l}\text { Mean } \\
\text { (Obs.) } \\
\triangle C O M<1 \%\end{array}$ & $\begin{array}{c}13.77 \\
72\end{array}$ & $\begin{array}{c}94.29 \\
72\end{array}$ & $\begin{array}{c}12.00 \\
72\end{array}$ & $\begin{array}{c}24.24 \\
72\end{array}$ & $\begin{array}{c}-5.61 \\
61\end{array}$ \\
\hline $\begin{array}{l}\text { Mean } \\
\text { (Obs.) } \\
\text { T-statistic of } \\
\text { the mean Test }\end{array}$ & $\begin{array}{c}11.68 \\
11 \\
2.690 * * *\end{array}$ & $\begin{array}{c}-47.45 \\
11 \\
3.590 * * *\end{array}$ & $\begin{array}{c}7.30 \\
11 \\
6.330 * * *\end{array}$ & $\begin{array}{c}26.31 \\
11 \\
-2.950 \\
\end{array}$ & $\begin{array}{c}14.69 \\
11 \\
-4.650\end{array}$ \\
\hline$\triangle T R A D>3 \%$ & & & & & \\
\hline $\begin{array}{l}\text { Mean } \\
\text { (Obs.) } \\
\triangle T R A D<1 \%\end{array}$ & $\begin{array}{c}15.05 \\
23\end{array}$ & $\begin{array}{c}-49.63 \\
23\end{array}$ & $\begin{array}{c}13.01 \\
23\end{array}$ & $\begin{array}{c}20.39 \\
23\end{array}$ & $\begin{array}{c}-15.54 \\
21\end{array}$ \\
\hline $\begin{array}{l}\text { Mean } \\
\text { (Obs.) } \\
\text { T-statistic of } \\
\text { the mean Test }\end{array}$ & $\begin{array}{c}14.02 \\
53\end{array}$ & $\begin{array}{c}-15.73 \\
53\end{array}$ & $\begin{array}{c}11.62 \\
53\end{array}$ & $\begin{array}{c}26.73 \\
53\end{array}$ & $\begin{array}{c}0.22 \\
44\end{array}$ \\
\hline
\end{tabular}

T-statistics test for the null:"Risk/Insolvency growth is not higher for banks which have actively diversified their activities on the whole period". ***, ** and * indicate significance respectively at the $1 \%, 5 \%$ and $10 \%$ levels for a unilateral test.

Variable definitions: $\triangle N N I I=$ mean of the annual growth rate of the ratio of net non interest income to net operating income; $\triangle C O M=$ mean of the annual growth rate of the ratio of net commission income to net operating income; $\triangle T R A D=$ mean of the annual growth rate of the ratio of net trading income to net operating income; $\triangle S D R E T$ = mean of the annual growth rate of the standard deviation of daily stock returns; $\triangle B E T A=$ mean of the annual growth rate of the market model beta; $\triangle R S P E C=$ mean of the annual growth rate of the standard deviation of the market model residual; $\triangle M D Z$ = mean of the annual growth rate of the market data based Z-score; $\triangle D D=$ mean of the annual growth rate of the distance to default.

${ }^{a}$ The values taken by MDZ and DD are always positive. Tests are carried out by considering the opposite values of $\triangle M D Z$ and $\triangle D D$.

\footnotetext{
${ }^{12}$ The growth rate of each variable is computed as the mean of annual growth rates.
} 
Our results (Mean tests) do not systematically display a significant larger increase (higher growth rate) in risk and insolvency risk indicators for banks which experienced a relatively sharper rise in non interest income over the sample period ( Table 4). However, when considering the two components of net non interest income it appears that banks which have engaged into fee-based activities exhibit significantly higher growth rates of risk indicators, a result which is not observed for banks which have mainly expanded their non traditional activities into trading.

To check the stability of our results, we also run our tests considering two criteria simultaneously. We isolate banks that experienced an annual growth rate of diversification higher than $3 \%$ controlling for the relative position of each bank with respect to the average level of diversification in our sample (Table 5). First, compared to the previous procedure, we exclude from our panel banks that exhibit a high growth rate (greater than 3\%) in diversification but which nevertheless do not reach, in 2002 (end of sample period), a higher diversification level than the full sample mean in 2002. Second, we also exclude banks that reach a higher level of diversification (compared to the full sample mean) at the end of 2002 but with a relatively low diversification growth rate (lower than $3 \%$ ) over the sample period. Based on this segmentation our tests show a higher increase in risk for banks which have developed non interest activities and which simultaneously exhibit the highest rates of diversification in 2002. But once again, the analysis of the subcomponents of net non interest income shows that this result is driven by the expansion of fee-based activities. Banks which highly shifted towards trading activities do not exhibit a higher increase in risk.

On the whole, consistent with some studies on U.S. banks, our results show that the shift from traditional intermediation activities to non-interest income activities is associated with higher bank risk. However, when we consider the different sources of non traditional income, we find that the positive link between the share of trading revenue and risk is weaker than for US banks (see Stiroh (2004)). The increase in risk is actually mostly driven by greater reliance on fee-based activities. This suggests that the European banking industry might have experienced different changes and a possible explanation for the positive link between risk and the development of commission and fee based activities is that the supply of fee-based services might have altered bank loan pricing behaviour. This is a challenge for better understanding the link between risk and fee-based activities as well as the determinants of banks' interest margin setting which therefore deserve a closer attention. 


\section{Table 5. Growth rate, level of diversification and growth rate of risk for European listed banks (1996-2002)}

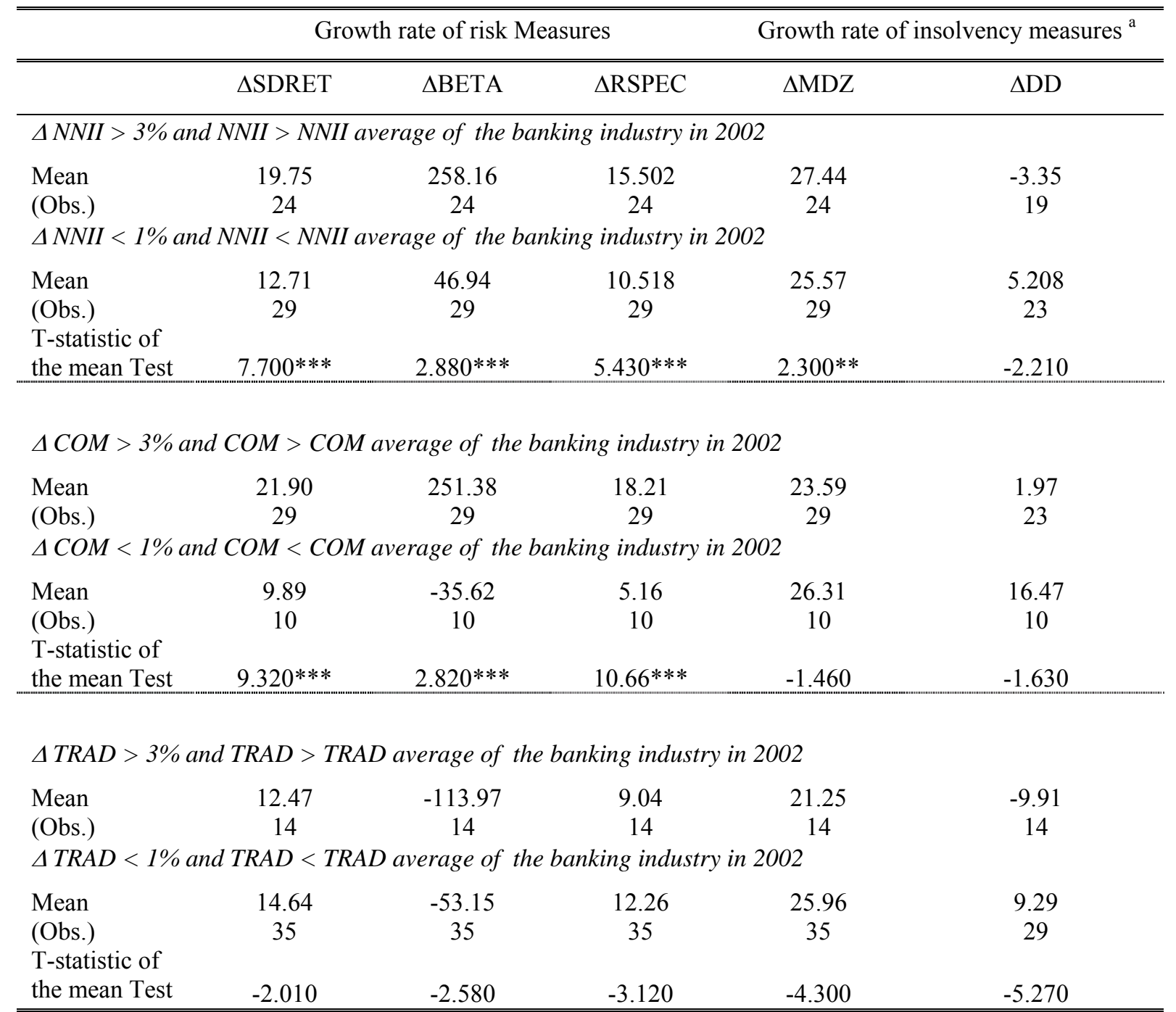

T-statistics test for the null: "Risk/Insolvency growth is not higher for banks which have actively diversified their activities on the whole period and have reached a relatively high level of diversification in 2002". ***, ** and * indicate significance respectively at the $1 \%, 5 \%$ and $10 \%$ levels for a unilateral test.

Variable definitions: $\triangle N N I I=$ mean of the annual growth rate of the ratio of net non interest income to net operating income; $\triangle C O M=$ mean of the annual growth rate of the ratio of net commission income to net operating income; $\triangle T R A D=$ mean of the annual growth rate of the ratio of net trading income to net operating income; $\triangle S D R E T$ = mean of the annual growth rate of the standard deviation of daily returns; $\triangle B E T A=$ mean of the annual growth rate of the market model beta; $\triangle R S P E C$ = mean of the annual growth rate of the standard deviation of the market model residual; $\triangle M D Z=$ mean of the annual growth rate of the market data based Zscore; $\triangle D D=$ mean of the annual growth rate of the distance to default.

${ }^{a}$ The values taken by $M D Z$ and DD are always positive. Tests are carried out by considering the opposite values of $\triangle M D Z$ and $\triangle D D$. 


\section{Lending rate and non traditional activities}

In this section we investigate the link between the pricing of loans (interest rate setting) and the shift towards non interest activities raising the issue of cross-selling of loans and fee-based activities. More precisely, our aim is to examine the hypothesis that banks have used lending as a loss leader in order to capture customers to sell additional non traditional products. Our assumption is that banks may require lower rates on their lending activities, underpricing credit risk which may in turn increase their overall risk level. Consequently, the price banks charge for loans should be a decreasing function of non-interest income and, particularly, commission and fee income because granting a (long term) loan increases the probability of actually selling fee generating products to a core customer while the prospects of gaining from other non traditional activities, such as trading activities, remain unchanged. Therefore, we further investigate the determinants of the lending rate by distinguishing commission and fee income and trading income.

We explore this issue by focusing on the determinants of the lending risk premium, i.e. the lending rate charged by the bank minus the risk free interest rate, using several definitions. The risk premium on loans (traditional activities) is first proxied by two different spread measures: W_SPREAD which is the difference between the ratio of net interest income to total earning assets and the 10 year government bond rate and N_SPREAD which is equal to the lending rate (determined as the ratio of interest from loans to net loans) minus the 10 year government bond rate $^{13}$. For consistency with previous studies, we also consider the broader issue of bank interest margin setting with two measures of the net interest margin, frequently used in the bank interest margin literature (Ho and Saunders, 1981; Angbazo, 1997; Wong, 1997; Saunders and Schumacher, 2000), W_MARGIN which is the ratio of net interest income to total earning assets and N_MARGIN which is defined as the difference between the two following ratios: $i$ / the ratio of interest income from loans to net loans and ii/ the ratio of interest expenses to total liabilities (defined as total assets minus total equity).

Relying on the optimal bank interest margin literature (Klein, 1971; Monti, 1972; Ho and Saunders, 1981; Angbazo, 1997; Wong, 1997; Saunders and Schumacher, 2000; Drakos, 2003; Maudos and Guevara, 2004), we first selected a set of variables (see Table 6) which are considered in most studies aiming to capture the determinants of bank loan pricing to which we added the diversification variables defined above. More precisely, four models are defined for each dependant variable.

\footnotetext{
${ }^{13}$ Results are not affected when a short risk free rate (3months) is used instead of the long rate.
} 


\section{Table 6. Specification of spread and margin equations}

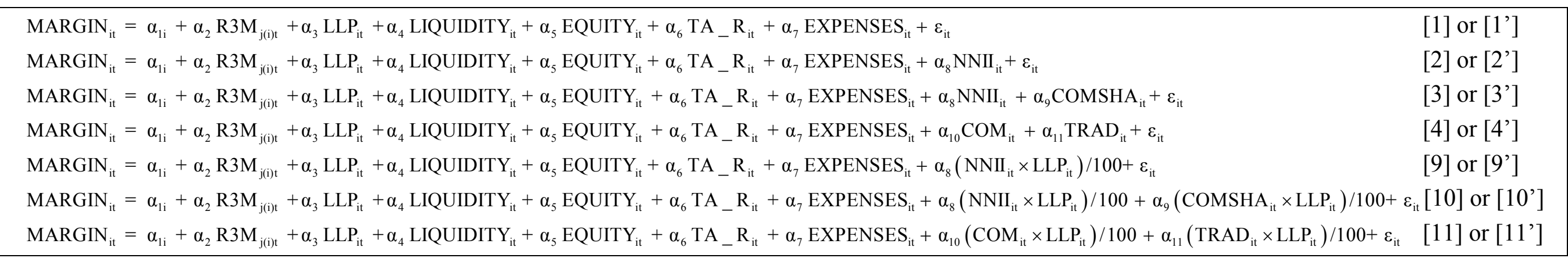

\begin{tabular}{|c|c|}
\hline $\operatorname{SPREAD}_{\mathrm{it}}=\beta_{1 \mathrm{i}}+\beta_{2}$ VR3M $_{\mathrm{jt}}+\beta_{3}$ LLP $_{\mathrm{it}}+\beta_{4}$ EQUITY $_{\mathrm{it}}+\beta_{5} \mathrm{TA}_{-} \mathrm{R}_{\mathrm{it}}+\beta_{6}$ EXPENSES $_{\mathrm{it}}+\varepsilon_{\mathrm{it}}$ & {$[5]$ or $\left[5^{\prime}\right]$} \\
\hline SPREAD $_{\mathrm{it}}=\beta_{1 \mathrm{i}}+\beta_{2}$ VR3M $_{\mathrm{jt}}+\beta_{3}$ LLP $_{\mathrm{it}}+\beta_{4}$ EQUITY $_{\mathrm{it}}+\beta_{5} \mathrm{TA}_{-} \mathrm{R}_{\mathrm{it}}+\beta_{6}$ EXPENSES $_{\mathrm{it}}+\beta_{7} \mathrm{NNII}_{\mathrm{it}}+\varepsilon_{\mathrm{it}}$ & {$[6]$ or $\left[6^{\prime}\right]$} \\
\hline $\operatorname{SPREAD}_{\mathrm{it}}=\beta_{1 \mathrm{i}}+\beta_{2}$ VR3M $_{\mathrm{jt}}+\beta_{3} \mathrm{LLP}_{\mathrm{it}}+\beta_{4}$ EQUITY $_{\mathrm{it}}+\beta_{5} \mathrm{TA}_{-} \mathrm{R}_{\mathrm{it}}+\beta_{6}$ EXPENSES $_{\mathrm{it}}+\beta_{7} \mathrm{NNII}_{\mathrm{it}}+\beta_{8} \mathrm{COMSHA}_{\mathrm{it}}+\varepsilon_{\mathrm{it}}$ & [7] or [7’] \\
\hline SPREAD $_{\mathrm{it}}=\beta_{1 \mathrm{i}}+\beta_{2}$ VR3M $_{\mathrm{jt}}+\beta_{3}$ LLP $_{\mathrm{it}}+\beta_{4}$ EQUITY $_{\mathrm{it}}+\beta_{5} \mathrm{TA}_{-} \mathrm{R}_{\mathrm{it}}+\beta_{6}$ EXPENSES $_{\mathrm{it}}+\beta_{9} \mathrm{COM}_{\mathrm{it}}+\beta_{10}$ TRAD $_{\mathrm{it}}+\varepsilon_{\mathrm{it}}$ & [8] or [8'] \\
\hline $\operatorname{SPREAD}_{\mathrm{it}}=\beta_{1 \mathrm{i}}+\beta_{2}$ VR3M $_{\mathrm{jt}}+\beta_{3}$ LLP $_{\mathrm{it}}+\beta_{4}$ EQUITY $_{\mathrm{it}}+\beta_{5} \mathrm{TA}_{-} \mathrm{R}_{\mathrm{it}}+\beta_{6}$ EXPENSES $_{\mathrm{it}}+\beta_{7}\left(\mathrm{NNII}_{\mathrm{it}} \times \mathrm{LLP}\right) / 100+\varepsilon_{\mathrm{it}}$ & [12] or [12'] \\
\hline $\operatorname{SPREAD}_{\mathrm{it}}=\beta_{1 \mathrm{i}}+\beta_{2}$ VR3M $_{\mathrm{jt}}+\beta_{3}$ LLP $_{\mathrm{it}}+\beta_{4}$ EQUITY $_{\mathrm{it}}+\beta_{5} \mathrm{TA}_{-} \mathrm{R}_{\mathrm{it}}+\beta_{6}$ EXPENSES $_{\mathrm{it}}+\beta_{7}\left(\mathrm{NNII}_{\mathrm{it}} \times \operatorname{LLP}_{\mathrm{it}}\right) / 100+\beta_{8}\left(\mathrm{COMSHA}_{\mathrm{it}} \times \mathrm{LLP}_{\mathrm{it}}\right) / 100+\varepsilon_{\mathrm{it}}$ & [13] or [13'] \\
\hline SPREAD $_{\mathrm{it}}=\beta_{1 \mathrm{i}}+\beta_{2}$ VR3M $_{\mathrm{jt}}+\beta_{3}$ LLP $_{\mathrm{it}}+\beta_{4}$ EQUITY $_{\mathrm{it}}+\beta_{5} \mathrm{TA}_{-} \mathrm{R}_{\mathrm{it}}+\beta_{6}$ EXPENSES $_{\mathrm{it}}+\beta_{9} \mathrm{COM}_{\mathrm{it}}+\beta_{10}$ TRAD $_{\mathrm{it}}+\varepsilon_{\mathrm{it}}$ & [14] or [14'] \\
\hline
\end{tabular}

$i$ and $t$ are respectively indices for banks $i$ and time $t$;

MARGIN $_{\text {it }}$ is defined either as :

W_MARGIN $=$ net interest income/total earning assets (equations 1 to 4);

or $\mathrm{N}$ MARGIN = interest income from loans/net loans - interest expenses/total liabilities (equations 1' to 4');

SPREAD ${ }_{\text {it }}$ is defined either as :

$\mathrm{W}$ SPREAD $=$ net interest income/total earning assets - the 10 year government bond rate (equations 5 to 8 );

or N_SPREAD = interest from loans/net loans - the 10 year government bond rate (equations 5' to 8');

$\mathrm{R} 3 \mathrm{M}_{\mathrm{jt}}$ : the three months interbank rate for country $\mathrm{j}$ of bank $\mathrm{i}$ at time $\mathrm{t}$;
$\mathrm{VR} \mathrm{M}_{\mathrm{jt}}$ : Volatility of the three months interbank rate (standard deviation computed with daily data) for country $j$;

$\mathrm{LLP}_{\text {it }}=$ loan loss provisions/net loans;

LIQUIDITY $_{\text {it }}=$ net loans/deposits;

$\mathrm{EQUITY}_{\text {it }}=$ equity/total assets;

TA $R_{\text {it }}=$ total assets for bank $\mathrm{i}$ divided by the sum of the total assets of the banking system;

EXPENSES $_{\text {it }}=$ personnel expenses/total assets;

$\mathrm{NNII}_{\text {it }}=$ net non-interest income/total net operating income;

$\mathrm{COM}_{\mathrm{it}}=$ net commission and fee income/ total net operating income;

$\mathrm{TRAD}_{\text {it }}=$ net trading income/ total net operating income;

$\mathrm{COMSHA}_{\mathrm{it}}=$ net commission and fee income/ net non-interest income 
As a first step (equations [1] and [5]) we estimate the margin model and the spread model referring to a general specification often used in previous papers. For spread equations, the volatility (standard deviation) of the three months interbank rate (VR3M) measures uncertainty on the money market. Therefore, a higher risk premium should be required following a rise in interest rate volatility $\left(\beta_{2}>0\right)$. When dealing with margin equations, we substitute the level of the three months interbank rate (R3M) for its volatility (VR3M): an increase in the level of the risk free rate implies a higher opportunity cost $\left(\alpha_{2}>0\right)$. The ratio of loan loss provisions to net loans (LLP) is considered as a measure of borrowers default risk for both margin and spread equations. A higher premium should be charged by banks to offset higher credit risk $\left(\alpha_{3}\right.$ and $\left.\beta_{3}>0\right)$. The ratio of equity to total assets (EQUITY) is often used in the literature as a proxy of the degree of bank risk aversion. Firms which are more risk averse may require a higher spread to cover the higher cost of equity financing compared to other sources of funding $\left(\alpha_{5}\right.$ and $\left.\beta_{4}>0\right)$. The variable TA_R is introduced to proxy bank market power which is often associated with higher lending rates. Therefore, the expected sign of the coefficient is positive $\left(\alpha_{6}\right.$ and $\left.\beta_{5}>0\right)$. However, because of the "Too big to fail" effect, banks may prefer to decrease their risk premium $\left(\alpha_{6}\right.$ and $\left.\beta_{5}<0\right)$ in order to attract borrowers. Regarding personnel expenses (EXPENSES) the literature provides mixed results on the expected coefficient. Because screening and monitoring of borrowers require higher personnel costs, the default risk premium charged on loans can be lower $\left(\alpha_{7}\right.$ and $\left.\beta_{6}<0\right)$. Conversely, as the cost of granting loans increases with personnel expenses banks should charge a higher premium $\left(\alpha_{7}\right.$ and $\left.\beta_{6}>0\right)$. We also consider liquidity risk for margin equations measured as the ratio of net loans to deposits. As the ratio increases, liquidity risk increases implying a higher margin set by banks $\left(\alpha_{4}>0\right)$.

By augmenting several specifications of the standard model with diversification variables (equations [2] to [4] for margin setting and equations [6] to [8] for spread determinants) our aim is to capture loan pricing implications of the degree of bank diversification and to check for the robustness of results. If banks use lending as a loss leader, we expect a negative coefficient for the variable NNII which measures product diversification $\left(\alpha_{8}\right.$ and $\left.\beta_{7}<0\right)$ and for COMSHA, COM and TRAD which proxy the structure of diversification $\left(\alpha_{9}, \alpha_{10}, \alpha_{11}, \beta_{8}, \beta_{9}\right.$ and $\left.\beta_{10}<0\right)$. To further investigate this hypothesis we also consider alternative specifications where interacting variables are introduced to capture the 
impact of non interest generating activities on the extent to which credit risk is actually taken into account in loan interest rate setting.

Tables 7 and 8 show the results which were obtained with two-way fixed effect panel data estimations ${ }^{14}$. OLS cross section results for 1996 and 2002 are presented in Tables A4, A5, A6 and A7 in the Appendix. On the whole, the coefficients of the standard variables considered in the literature on bank interest margin are significant and have the expected sign. As expected, the credit risk proxy (LLP) is significant and positive in each regression. This result is consistent with the hypothesis that banks charge higher lending rates for riskier loans.

The net non-interest income variable (NNII) introduced in equations [2] and [6] has a significant negative coefficient in all our panel data estimations. These results suggest possible cross-selling of loans and non interest generating activities.

To investigate this hypothesis, we consider as a first step non traditional income activities at a disaggregated level. More precisely, we decompose these activities into feebased revenue and trading income. Equations [4] and [8] in tables 7 and 8 show that the coefficient of the share of commission and fee-based income variable (COM) is negative and significant. Thus, up to this stage our results are consistent with the hypothesis that banks decrease their lending rate when they are more reliant on fee generating products. Conversely the coefficient of the variable indicating the extent to which bank revenue is trading based (TRAD) is not significantly different from 0 except when the dependant variable is the margin from all interest generating activities (W_MARGIN) comprising loans but also other market assets. Therefore, our findings do not support evidence of any correlation between loan prices and the relative importance of income generated by trading activities.

As a second step, because our results suggest that banks may actually be cross-selling their products using loans as a loss leader and possibly underpricing credit risk, we further explore this issue by introducing interacting variables in our estimations to capture the

\footnotetext{
${ }^{14}$ Fisher tests are used to determine if our data require the utilization of panel estimation or pooled estimation techniques. Heterogeneity across units leads us to use panel data estimations. Most panel data models are estimated under either fixed-effects or random-effects assumptions. We perform a Hausman test (see Hausman, 1978) to choose between these two basic models. All the equations have been corrected from heteroscedasticity following White's methodology. Because all banks do not report information on the interest they charge on loans, 281 banks are excluded from our estimations.

Several robustness checks were performed. To deal with the presence of possible trends (decrease in interest margins due to higher competition and higher proportion of non interest generating activities at the end of the sample period), we ran cross-section estimations for each year and we also introduced a time trend in our panel data models. We also estimated the equation by first differencing the variables. Our conclusions, regarding the inclusion of product diversification variables, are unaltered. The results of these estimations are available from the authors upon request.
} 
presence of such a behaviour via a negative impact on loan interest rates (equations 9 to 14 in Tables 9 and 10). Hence, the interacting variables stand for the mixed effect on risk pricing via the interest rate spread (risk premium) banks require on their loans. In this sense, banks may decrease their lending rate to attract or to retain borrowers which are potential customers for fee generating products. But their exposure to default risk may consequently become higher which can be captured by a fall in the spread (risk premium). The interacting variables are defined as the credit risk variable (LLP) multiplied by each of the non interest income variables (NNII, COMSHA, COM and TRAD). Whereas almost all the interacting variables are significant and negative in the margin equations (when the dependant variable is W_MARGIN or N_MARGIN, Table 9) only the variables involving commission and fee income are significant in the spread equations (W_SPREAD or N_SPREAD, Table 10). Therefore, according to our results the non interest income subsidy effect distorts credit risk pricing only in the case of commission and fee activities (measured by the sum of the coefficients of LLP (positive) and COM*LLP (negative) which are highly significant in Table 10) ${ }^{15}$ whereas the development of trading activities does not significantly affect the link between credit risk and the pricing of loans.

\section{Conclusion}

The objective of this study was to analyze the risk implications of the trend towards stronger product diversification in the European banking industry. Our study shows that banks which have expanded into non-interest income activities present a higher level of risk than banks which mainly perform traditional intermediation activities. A closer investigation shows that risk is mainly positively correlated with the share of fee-based activities but not with trading activities. This result also holds when we consider the link between risk changes and higher diversification within our sample period. In addition to the plausible implications addressed in previous papers we test for a possible cross-selling behaviour of interest and non-interest products by analysing the determinants of the risk premium charged by banks on

\footnotetext{
${ }^{15}$ To assess the overall effect of credit risk on the dependent variable, one needs to consider not only the coefficient of LLP but also the coefficients of the interacting variables (NNII*LLP, COMSHA*LLP, COM*LLP or TRAD*LLP). More precisely, if we consider equation $12^{\prime}$ 'in table 10 , the impact of credit risk on the dependent variable for a given bank which exhibits, for a given year, a value of NNII equal to $40 \%$, is equal to the coefficient of LLP + (the coefficient of NNII*LLP * the value of NNII taken by the bank) : $0.664+(-1.097$ * 0.4 ) that is a value equal to 0.225 . In this case credit risk is not fully taken into account in the loan rate setting process (a coefficient of 0.225 instead of a coefficient of 0.664 without the cross-selling effect).
} 
their loans. Specifically, we find that borrower default risk is underpriced in lending rates and on the whole our results show that higher reliance on fee-based activities is associated with lower lending rates suggesting that banks may use loans as a loss leader raising the issue of how cross-selling strategies should be addressed by regulators to control for bank risk. Conversely, we do not find evidence of a positive link between bank risk and the growing share of trading activities in bank income statements. 
Table 7. Two way fixed effect regression (LSDV): impact of product diversification on net interest margin for European banks (1996-2002)

\begin{tabular}{|c|c|c|c|c|c|c|c|c|c|c|c|}
\hline Equation & $\begin{array}{c}\text { R3M } \\
(+)\end{array}$ & $\begin{array}{l}\text { LLP } \\
(+)\end{array}$ & $\begin{array}{c}\text { LIQUIDITY } \\
(+)\end{array}$ & $\begin{array}{l}\text { EQUITY } \\
(+)\end{array}$ & $\begin{array}{c}\text { EXPENSES } \\
(+/-)\end{array}$ & $\begin{array}{l}\text { TA_R } \\
(+/-)\end{array}$ & $\begin{array}{l}\text { NNII } \\
(-)\end{array}$ & $\begin{array}{c}\text { COMSHA } \\
(-)\end{array}$ & $\begin{array}{c}\mathrm{COM} \\
(-)\end{array}$ & $\begin{array}{c}\text { TRAD } \\
(-)\end{array}$ & $\mathrm{R}^{2}$ \\
\hline \multicolumn{12}{|c|}{ Dependant variable: W_MARGIN (2342 obs.) } \\
\hline$[1]$ & $\begin{array}{c}0.115^{* * *} \\
(5.622)\end{array}$ & $\begin{array}{c}0.071 * * * \\
(3.850)\end{array}$ & $\begin{array}{l}0.000^{*} \\
(1.760)\end{array}$ & $\begin{array}{c}0.035^{* * *} \\
(4.715)\end{array}$ & $\begin{array}{c}0.404 * * * \\
(6.433)\end{array}$ & $\begin{array}{c}0.137 \\
(0.094)\end{array}$ & - & - & - & - & 0.920 \\
\hline$[2]$ & $\begin{array}{c}0.100 * * * \\
(3.955)\end{array}$ & $\begin{array}{c}0.047 * * \\
(2.443)\end{array}$ & $\begin{array}{c}-0.000 \\
(-0.076)\end{array}$ & $\begin{array}{c}0.032 * * * \\
(4.449)\end{array}$ & $\begin{array}{c}0.415 * * * \\
(6.653)\end{array}$ & $\begin{array}{c}0.304 \\
(0.275)\end{array}$ & $\begin{array}{c}-0.019 * * * \\
(-5.308)\end{array}$ & - & - & - & 0.929 \\
\hline [3] & $\begin{array}{c}0.098 * * * \\
(3.921)\end{array}$ & $\begin{array}{c}0.047 * * \\
(2.409)\end{array}$ & $\begin{array}{c}-0.000 \\
(-0.062)\end{array}$ & $\begin{array}{c}0.032 * * * \\
(4.406)\end{array}$ & $\begin{array}{c}0.413 * * * \\
(6.558)\end{array}$ & $\begin{array}{c}0.344 \\
(0.316)\end{array}$ & $\begin{array}{c}-0.020 * * * \\
(-5.243)\end{array}$ & $\begin{array}{c}-0.019 \\
(-1.455)\end{array}$ & - & - & 0.929 \\
\hline [4] & $\begin{array}{c}0.067 * * * \\
(3.890)\end{array}$ & $\begin{array}{c}0.048 * * \\
(2.608)\end{array}$ & $\begin{array}{c}0.000 \\
(0.216)\end{array}$ & $\begin{array}{c}0.028 * * * \\
(3.993)\end{array}$ & $\begin{array}{c}0.420 * * * \\
(6.415)\end{array}$ & $\begin{array}{c}-0.665 \\
(-0.582)\end{array}$ & - & - & $\begin{array}{c}-0.037 * * * \\
(-8.911)\end{array}$ & $\begin{array}{c}-0.016 * * * \\
(-8.026)\end{array}$ & 0.934 \\
\hline \multicolumn{12}{|c|}{ Dependant variable: N_MARGIN (2342 obs.) } \\
\hline$\left[1^{\prime}\right]$ & $\begin{array}{c}0.140 * * * \\
(3.923)\end{array}$ & $\begin{array}{c}0.149 * * * \\
(5.067)\end{array}$ & $\begin{array}{l}-0.001^{*} \\
(-1.680)\end{array}$ & $\begin{array}{l}-0.070^{*} \\
(-1.769)\end{array}$ & $\begin{array}{c}0.204 \\
(1.635)\end{array}$ & $\begin{array}{c}1.672 \\
(0.691)\end{array}$ & - & - & - & - & 0.799 \\
\hline [2'] & $\begin{array}{c}0.159 * * * \\
(5.349)\end{array}$ & $\begin{array}{c}0.114 * * * \\
(3.390)\end{array}$ & $\begin{array}{c}-0.000 * * * \\
(-4.861)\end{array}$ & $\begin{array}{c}-0.022 \\
(-0.819)\end{array}$ & $\begin{array}{c}0.135 \\
(1.045)\end{array}$ & $\begin{array}{c}1.707 \\
(0.748)\end{array}$ & $\begin{array}{c}-0.010 * * \\
(-1.967)\end{array}$ & - & - & - & 0.843 \\
\hline [3'] & $\begin{array}{c}0.158 * * * \\
(5.232)\end{array}$ & $\begin{array}{c}0.110^{* * *} \\
(3.190)\end{array}$ & $\begin{array}{c}-0.000 * * * \\
(-4.834)\end{array}$ & $\begin{array}{c}-0.023 \\
(-0.837)\end{array}$ & $\begin{array}{c}0.132 \\
(1.015)\end{array}$ & $\begin{array}{c}1.641 \\
(0.727)\end{array}$ & $\begin{array}{l}-0.010^{*} \\
(-1.800)\end{array}$ & $\begin{array}{c}-0.009 \\
(-0.576)\end{array}$ & - & - & 0.843 \\
\hline [4'] & $\begin{array}{c}0.200 * * * \\
(5.072)\end{array}$ & $\begin{array}{c}0.033 \\
(1.307)\end{array}$ & $\begin{array}{c}-0.000 * * * \\
(-4.342)\end{array}$ & $\begin{array}{c}-0.010 \\
(-0.310)\end{array}$ & $\begin{array}{c}0.082 \\
(0.461)\end{array}$ & $\begin{array}{c}4.262 \\
(1.089)\end{array}$ & - & - & $\begin{array}{c}-0.017 * * \\
(-1.986)\end{array}$ & $\begin{array}{c}-0.006 \\
(-1.357)\end{array}$ & 0.839 \\
\hline
\end{tabular}

Variable definitions: W MARGIN = net interest income/total earning assets; $N$ MARGIN = (interest income from loans/net loans) - interest expenses/total liabiities; LIQUIDITY $_{i t}=$ net loans/deposits; TA_R $R_{i t}=$ total assets for bank $i$ divided by the sum of the total asset of the banking system; $R 3 M_{j t}=$ the three months interbank rate; LLP $=$ loan loss provisions/net loans for bank $i$ at time $t ; E_{\text {EUITY }}=$ equity/total assets for bank $i$ at time $t$; EXPENSES it $=$ personnel expenses/total assets for bank $i$ at time $t$; $N_{N I I} I_{i t}=$ net non-interest income/ total net operating income for bank $i$ at time $t$; $C_{1} M_{i t}=$ net commission and fee income/ total net operating income for bank $i$ at time $t$; $T R A D_{i t}=$ net trading income/ total net operating income for bank i at time $t ; C_{C O M S H A}=$ net commission and fee income/ net non-interest income. 
Table 8. Two way fixed effect regression (LSDV): impact of product diversification on risk premium for European banks (1996-2002)

\begin{tabular}{|c|c|c|c|c|c|c|c|c|c|c|}
\hline Equation & $\begin{array}{c}\text { VR3M } \\
(+)\end{array}$ & $\begin{array}{l}\text { LLP } \\
(+)\end{array}$ & $\begin{array}{c}\text { EQUITY } \\
(+)\end{array}$ & $\begin{array}{c}\text { EXPENSES } \\
(+/-)\end{array}$ & $\begin{array}{c}\text { TA_R } \\
(+/-)\end{array}$ & $\begin{array}{l}\text { NNII } \\
(-)\end{array}$ & $\begin{array}{c}\text { COMSHA } \\
(-)\end{array}$ & $\begin{array}{c}\mathrm{COM} \\
(-)\end{array}$ & $\begin{array}{c}\text { TRAD } \\
(-)\end{array}$ & $\mathrm{R} 2$ \\
\hline \multicolumn{11}{|c|}{ Dependant variable: W_SPREAD (2342 obs.) } \\
\hline$[5]$ & $\begin{array}{c}0.942 \\
(1.527)\end{array}$ & $\begin{array}{c}0.145^{* * *} \\
(3.065)\end{array}$ & $\begin{array}{c}0.007 \\
(0.517)\end{array}$ & $\begin{array}{l}0.335^{*} \\
(1.740)\end{array}$ & $\begin{array}{c}9.924 \\
(1.537)\end{array}$ & - & - & - & - & 0.776 \\
\hline$[6]$ & $\begin{array}{c}0.899 \\
(1.516)\end{array}$ & $\begin{array}{c}0.136 * * * \\
(2.817)\end{array}$ & $\begin{array}{c}-0.014 * * \\
(-2.097)\end{array}$ & $\begin{array}{c}0.629 * * * \\
(4.698)\end{array}$ & $\begin{array}{c}9.608 \\
(1.414)\end{array}$ & $\begin{array}{c}-0.015^{* * *} \\
(-2.642)\end{array}$ & - & - & - & 0.790 \\
\hline$[7]$ & $\begin{array}{c}0.891 \\
(1.526)\end{array}$ & $\begin{array}{c}0.138 * * * \\
(2.852)\end{array}$ & $\begin{array}{c}-0.015 * * \\
(-2.068)\end{array}$ & $\begin{array}{c}0.627 * * * \\
(4.699)\end{array}$ & $\begin{array}{c}9.550 \\
(1.424)\end{array}$ & $\begin{array}{c}-0.016^{* * *} \\
(-2.659)\end{array}$ & $\begin{array}{l}-0.065^{*} \\
(-1.853)\end{array}$ & - & - & 0.791 \\
\hline [8] & $\begin{array}{c}0.733 \\
(1.528)\end{array}$ & $\begin{array}{c}0.124 * * \\
(2.430)\end{array}$ & $\begin{array}{c}0.002 \\
(0.116)\end{array}$ & $\begin{array}{c}0.251 \\
(1.343)\end{array}$ & $\begin{array}{c}6.978 \\
(1.322)\end{array}$ & & - & $\begin{array}{c}-0.053 * * * \\
(-2.838)\end{array}$ & $\begin{array}{c}-0.001 \\
(-0.262)\end{array}$ & 0.791 \\
\hline \multicolumn{11}{|c|}{ Dependant variable: N_SPREAD (2342 obs.) } \\
\hline$\left[5^{\prime}\right]$ & $\begin{array}{c}0.973^{*} \\
(1.669)\end{array}$ & $\begin{array}{c}0.231 * * * \\
(4.697)\end{array}$ & $\begin{array}{c}-0.006 \\
(-0.296)\end{array}$ & $\begin{array}{c}0.224 * * * \\
(2.914)\end{array}$ & $\begin{array}{c}4.417 \\
(1.429)\end{array}$ & - & - & - & - & 0.815 \\
\hline$\left[6^{\prime}\right]$ & $\begin{array}{c}0.954^{*} \\
(1.676)\end{array}$ & $\begin{array}{c}0.240 * * * \\
(5.201)\end{array}$ & $\begin{array}{c}-0.013 \\
(-0.589)\end{array}$ & $\begin{array}{c}0.324 * * * \\
(5.205)\end{array}$ & $\begin{array}{c}4.180 \\
(1.351)\end{array}$ & $\begin{array}{c}-0.014 * * * \\
(-3.012)\end{array}$ & - & - & - & 0.818 \\
\hline [7'] & $\begin{array}{c}0.949^{*} \\
(1.685)\end{array}$ & $\begin{array}{c}0.234 * * * \\
(5.093)\end{array}$ & $\begin{array}{c}-0.014 \\
(-0.620)\end{array}$ & $\begin{array}{c}0.316^{* * * *} \\
(5.077)\end{array}$ & $\begin{array}{c}4.091 \\
(1.318)\end{array}$ & $\begin{array}{c}-0.014 * * * \\
(-2.784)\end{array}$ & $\begin{array}{c}-0.053 * * \\
(-2.257)\end{array}$ & - & - & 0.818 \\
\hline [8'] & $\begin{array}{c}0.717 \\
(1.177) \\
\end{array}$ & $\begin{array}{c}0.141^{* * *} \\
(3.195) \\
\end{array}$ & $\begin{array}{c}-0.006 \\
(-0.293) \\
\end{array}$ & $\begin{array}{c}0.197 * * \\
(2.165) \\
\end{array}$ & $\begin{array}{c}7.523 * * * \\
(3.558) \\
\end{array}$ & - & - & $\begin{array}{c}-0.046^{* *} \\
(-2.619)\end{array}$ & $\begin{array}{l}-0.006^{*} \\
(-1.943) \\
\end{array}$ & 0.807 \\
\hline
\end{tabular}

Variable definitions: W_SPREAD = the ratio of net interest income to total earning assets - the 10 year government bond rate; $N$ SPREAD = lending rate determined as the ratio of interest from loans to net loans - the 10 year government bond rate; TA_ $R_{i t}=$ total assets for bank $i$ divided by the sum of the total asset of the banking system; $V R 3 M_{j t}=$ volatility of the three months interbank rate (standard deviation computed with daily data) for country j; LLP it $=$ loan loss provisions/net loans for bank i at time $t ;$ $E_{\text {QUITY }}{ }_{i t}=$ equity/total assets for bank $i$ at time $t ;$ EXPENSES $_{\text {it }}=$ personnel expenses/total assets for bank $i$ at time $t ;$ NNII $_{i t}=$ net non-interest income/ total net operating income for bank $i$ at time $t$; $C O M_{i t}=$ net commission and fee income/ total net operating income for bank $i$ at time $t$; TRAD $D_{i t}=$ net trading income/ total net operating income for bank i at time t; COMSHA ${ }_{i t}=$ net commission and fee income/ net non-interest income. 
Table 9. Two way fixed effect regression (LSDV): impact of interacting variables (product diversification*credit risk) on net interest margin for European banks (1996-2002)

\begin{tabular}{|c|c|c|c|c|c|c|c|c|c|c|c|}
\hline & $\begin{array}{c}\text { R3M } \\
(+)\end{array}$ & $\begin{array}{l}\text { LLP } \\
(+)\end{array}$ & $\begin{array}{c}\text { LIQUIDITY } \\
(+)\end{array}$ & $\begin{array}{c}\text { EQUITY } \\
(+)\end{array}$ & $\begin{array}{c}\text { EXPENSES } \\
(+/-)\end{array}$ & $\begin{array}{c}\text { TA_R } \\
(+/-)\end{array}$ & $\begin{array}{l}\text { NNII*LLP } \\
/ 100 \\
(-)\end{array}$ & $\begin{array}{c}\text { COMSHA *LLP } \\
/ 100 \\
(-)\end{array}$ & $\begin{array}{c}\text { COM*LLP } \\
/ 100 \\
(-)\end{array}$ & $\begin{array}{c}\text { TRAD*LLP } \\
/ 100 \\
(-)\end{array}$ & $\mathrm{R}^{2}$ \\
\hline \multicolumn{12}{|c|}{ Dependant variable: W_MARGIN (2342 obs.) } \\
\hline$[9]$ & $\begin{array}{c}0.108^{* * *} \\
(5.590)\end{array}$ & $\begin{array}{c}0.234 * * * \\
(4.056)\end{array}$ & $\begin{array}{c}0.000 \\
(1.517)\end{array}$ & $\begin{array}{c}0.037 * * * \\
(5.987)\end{array}$ & $\begin{array}{c}0.390^{* * *} \\
(6.640)\end{array}$ & $\begin{array}{c}0.232 \\
(0.169)\end{array}$ & $\begin{array}{c}-0.452 * * * \\
(-3.343)\end{array}$ & - & - & - & 0.922 \\
\hline$[10]$ & $\begin{array}{c}0.106^{* * *} \\
(5.641)\end{array}$ & $\begin{array}{c}0.245^{* * *} * \\
(3.763)\end{array}$ & $\begin{array}{c}0.000 \\
(1.508)\end{array}$ & $\begin{array}{c}0.037 * * * \\
(5.941)\end{array}$ & $\begin{array}{c}0.388 * * * \\
(6.542)\end{array}$ & $\begin{array}{c}0.285 \\
(0.208)\end{array}$ & $\begin{array}{c}-0.461 * * * \\
(-3.233)\end{array}$ & $\begin{array}{c}-1.198 \\
(-0.886)\end{array}$ & - & - & 0.922 \\
\hline$[11]$ & $\begin{array}{c}0.102 * * * \\
(5.492)\end{array}$ & $\begin{array}{c}0.273 * * * \\
(5.453)\end{array}$ & $\begin{array}{c}0.000 \\
(1.621)\end{array}$ & $\begin{array}{c}0.036 * * * \\
(5.656)\end{array}$ & $\begin{array}{c}0.394 * * * \\
(6.493)\end{array}$ & $\begin{array}{c}0.237 \\
(0.173) \\
\end{array}$ & - & - & $\begin{array}{c}-0.505^{* * *} \\
(-4.280)\end{array}$ & $\begin{array}{c}-0.215^{* *} \\
(-2.240)\end{array}$ & 0.923 \\
\hline \multicolumn{12}{|c|}{ Dependant variable: $N \_$MARGIN (2342 obs.) } \\
\hline$\left[9^{\prime}\right]$ & $\begin{array}{c}0.156 * * * \\
(5.700)\end{array}$ & $\begin{array}{c}0.412 * * * \\
(8.794)\end{array}$ & $\begin{array}{c}-0.000 * * * \\
(-5.112)\end{array}$ & $\begin{array}{c}-0.018 \\
(-0.694)\end{array}$ & $\begin{array}{c}0.115 \\
(0.981)\end{array}$ & $\begin{array}{c}2.157 \\
(0.866)\end{array}$ & $\begin{array}{c}-0.624 * * * \\
(-4.669)\end{array}$ & - & - & - & 0.843 \\
\hline$\left[10^{\prime}\right]$ & $\begin{array}{c}0.156^{* * *} \\
(5.509)\end{array}$ & $\begin{array}{c}0.392 * * * \\
(5.642)\end{array}$ & $\begin{array}{c}-0.000 * * * \\
(-5.079)\end{array}$ & $\begin{array}{c}-0.018 \\
(-0.689)\end{array}$ & $\begin{array}{c}0.111 \\
(0.949)\end{array}$ & $\begin{array}{c}2.134 \\
(0.869)\end{array}$ & $\begin{array}{c}-0.636 * * * \\
(-4.552)\end{array}$ & $\begin{array}{c}1.412 \\
(0.330)\end{array}$ & - & - & 0.844 \\
\hline [11'] & $\begin{array}{c}0.212 * * * \\
(6.361)\end{array}$ & $\begin{array}{c}0.332 * * * \\
(4.165)\end{array}$ & $\begin{array}{c}-0.000 * * * \\
(-4.465)\end{array}$ & $\begin{array}{c}-0.006 \\
(-0.179) \\
\end{array}$ & $\begin{array}{c}0.074 \\
(0.426) \\
\end{array}$ & $\begin{array}{c}4.717 \\
(1.226) \\
\end{array}$ & - & - & $\begin{array}{c}-0.589 * * * \\
(-2.674) \\
\end{array}$ & $\begin{array}{c}-0.752 * * * \\
(-2.298)\end{array}$ & 0.840 \\
\hline
\end{tabular}

Variable definitions: W MARGIN = net interest income/total earning assets; $N$ MARGIN = (interest income from loans/net loans) - interest expenses/total liabiities; LIQUIDITY $_{i t}=$ net loans/deposits; TA_R $R_{i t}=$ total assets for bank $i$ divided by the sum of the total asset of the banking system; $R 3 M_{j t}=$ the three months interbank rate; LLP ${ }_{\text {it }}$ $=$ loan loss provisions/net loans for bank i at time $t ; E_{\text {QUITY }}=$ equity/total assets for bank $i$ at time $t$; EXPENSES ${ }_{\text {it }}=$ personnel expenses/total assets for bank $i$ at time $t$; $N N I{ }^{*} L L P_{i t}=$ (net non-interest income/ total net operating income) $* L L P$ for bank $i$ at time $t ; C^{*}{ }^{*} L L P$ it $=$ (net commission and fee income/ total net operating income $) * L L P$ for bank $i$ at time $t ; T R A D * L L P$ it $=(\text { net trading income/ total net operating income })^{*} L L P$ for bank $i$ at time $t$; COMSHA*LLP ${ }_{i t}=($ net commission and fee income/ net non-interest income)*LLP. All the variables are expressed in \%. Therefore, the interacting variables are divided by 100 to obtain coefficients that can be directly compared to the coefficient of LLP. 
Table 10. Two way fixed effect regression (LSDV): impact of interacting variables (product diversification*credit risk) on risk premium for European banks (1996-2002)

\begin{tabular}{|c|c|c|c|c|c|c|c|c|c|c|}
\hline & $\begin{array}{c}\text { VR3M } \\
(+)\end{array}$ & $\begin{array}{c}\text { LLP } \\
(+)\end{array}$ & $\begin{array}{c}\text { EQUITY } \\
(+)\end{array}$ & $\begin{array}{c}\text { EXPENSES } \\
(+/-)\end{array}$ & $\begin{array}{c}\text { TA_R } \\
(+/-)\end{array}$ & $\begin{array}{c}\text { NNII*LLP/100 } \\
(-)\end{array}$ & $\begin{array}{c}\text { COMSHA } * \text { LLP/100 } \\
(-)\end{array}$ & $\begin{array}{c}\mathrm{COM}^{*} \mathrm{LLP} / 100 \\
(-)\end{array}$ & $\begin{array}{c}\text { TRAD*LLP/100 } \\
(-)\end{array}$ & $\mathrm{R} 2$ \\
\hline \multicolumn{11}{|c|}{ Dependant variable: W_SPREAD (2342 obs.) } \\
\hline$[12]$ & $\begin{array}{c}0.840 \\
(1.420)\end{array}$ & $\begin{array}{c}0.437 * * * \\
(3.805)\end{array}$ & $\begin{array}{c}-0.025 * * * \\
(-3.158)\end{array}$ & $\begin{array}{c}0.831 * * * \\
(7.022)\end{array}$ & $\begin{array}{c}9.203 \\
(1.631)\end{array}$ & $\begin{array}{c}-0.615 * * * \\
(-3.408)\end{array}$ & - & - & - & 0.789 \\
\hline$[13]$ & $\begin{array}{c}0.833 \\
(1.416)\end{array}$ & $\begin{array}{c}0.479 * * * \\
(4.293)\end{array}$ & $\begin{array}{c}-0.025 * * * \\
(-3.227)\end{array}$ & $\begin{array}{c}0.829 * * * \\
(6.977)\end{array}$ & $\begin{array}{c}9.172 \\
(1.640)\end{array}$ & $\begin{array}{c}-0.628 * * * \\
(-3.493)\end{array}$ & $\begin{array}{l}-4.114 * \\
(-1.744)\end{array}$ & - & - & 0.789 \\
\hline$[14]$ & $\begin{array}{c}0.788 \\
(1.402)\end{array}$ & $\begin{array}{c}0.598 * * * \\
(6.628)\end{array}$ & $\begin{array}{c}-0.024 * * * \\
(-3.125)\end{array}$ & $\begin{array}{c}0.829 * * * \\
(7.536)\end{array}$ & $\begin{array}{c}8.656 \\
(1.592)\end{array}$ & - & - & $\begin{array}{c}-1.218^{* * *} \\
(-8.289)\end{array}$ & $\begin{array}{c}-0.007 \\
(-0.149)\end{array}$ & 0.791 \\
\hline \multicolumn{11}{|c|}{ Dependant variable: N_SPREAD (2342 obs.) } \\
\hline [12’] & $\begin{array}{c}0.850 \\
(1.247)\end{array}$ & $\begin{array}{c}0.664 * * * \\
(5.311)\end{array}$ & $\begin{array}{c}-0.006 \\
(-0.224)\end{array}$ & $\begin{array}{c}0.333 * * * \\
(3.289)\end{array}$ & $\begin{array}{c}8.582 * * * \\
(4.325)\end{array}$ & $\begin{array}{c}-1.097 * * * \\
(-4.864)\end{array}$ & - & - & - & 0.807 \\
\hline [13’] & $\begin{array}{c}0.847 \\
(1.243)\end{array}$ & $\begin{array}{c}0.682 * * * \\
(5.279)\end{array}$ & $\begin{array}{c}-0.006 \\
(-0.252)\end{array}$ & $\begin{array}{c}0.331^{* * *} \\
(3.285)\end{array}$ & $\begin{array}{c}8.503 * * * \\
(4.261)\end{array}$ & $\begin{array}{c}-0.943 * * * \\
(-4.499)\end{array}$ & $\begin{array}{c}-5.407 \\
(-1.490)\end{array}$ & - & - & 0.808 \\
\hline [14'] & $\begin{array}{c}0.838 \\
(1.208)\end{array}$ & $\begin{array}{c}0.659 * * * \\
(5.972)\end{array}$ & $\begin{array}{c}-0.005 \\
(-0.188)\end{array}$ & $\begin{array}{c}0.327 * * * \\
(3.261)\end{array}$ & $\begin{array}{c}8.600 * * * \\
(4.303)\end{array}$ & - & - & $\begin{array}{c}-1.047 * * * \\
(-4.120)\end{array}$ & $\begin{array}{c}-0.701 \\
(-0.075)\end{array}$ & 0.807 \\
\hline
\end{tabular}

* and * indicate significance respectively at the 1\%, 5\% and 10\% levels. $t$-statistics are corrected for heteroskedasticity following White's methodology.

Variable definitions: W_SPREAD = the ratio of net interest income to total earning assets - the 10 year government bond rate; $N$ SPREAD = lending rate determined as the ratio of interest from loans to net loans - the 10 year government bond rate; TA_R $R_{\text {it }}=$ total assets for bank $i$ divided by the sum of the total asset of the banking system; $V R 3 M_{i t}=$ volatility of the three months interbank rate (standard deviation computed with daily data) for country j; LLP it $=$ loan loss provisions/net loans for bank $i$ at time $t$;

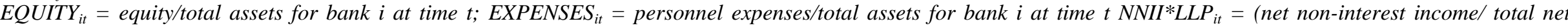
operating income $)^{*} L L P$ for bank $i$ at time $t ; C O M * L L P_{i t}=(\text { net commission and fee income/ total net operating income })^{*} L L P$ for bank $i$ at time $t$; TRAD*LLP ${ }_{i t}=($ net trading income/ total net operating income) $* L P$ for bank $i$ at time $t ; C O M S H A * L L P$ it $=$ (net commission and fee income/ net non-interest income) ${ }^{2} L P$. All the variables are expressed in \%. Therefore, the interacting variables are divided by 100 to obtain coefficients that can be directly compared to the coefficient of LLP. 


\section{References}

Acharya, V., Hasan, I., Saunders, A., 2002. The effects of focus and diversification on bank risk and return: evidence from individual bank loan portfolio.CEPR Discussion Paper $n^{\circ} 3252$. Allen, L., Jagtiani, J., 2000. The risk effect of combining banking, securities and insurance activities. Journal of Economics and Business 52(6), 485-497.

Angbazo, L., 1997. Commercial bank interest margins, default risk, interest-rate risk, and offbalance sheet banking. Journal of Banking and Finance 21(1), 55-87.

Black F., Scholes M., 1973. The pricing options and corporate liabilities. Journal of Political Economy, 637-654.

Boyd, J., Chang, C., Smith, D., 1998. Moral hazard under commercial and universal banking. Journal of Money, Credit and Banking 30(3).

Boyd, J., Graham, S., 1986. Risk, regulation, and bank holding company expansion. Federal Reserve Bank of Mineapolis, Quaterly Review, spring.

Boyd, J., Graham, G., 1988. The profitability and risk effects of allowing bank holding companies to merge with other financial firms: a simulation study. Federal Reserve Bank of Minneapolis, Quaterly Review, spring.

Boyd, J., Graham, G., Hewitt, R., 1993. Bank holding company mergers with nonblank financial firms, Journal of Banking and Finance 17, 43-63.

Boyd, J., Hanweck, G., Pithyachariyakul, P., 1980. Bank holding company diversification. Federal Reserve Bank of Chicago, Proceedings from a conference on Bank Structure and Competition, May, 105-120.

Demsetz, R., Strahan, P., 1997. Diversification, size, and risk at Bank Holding Companies. Journal of Money, Credit and Banking 29(3), 300-313.

De Young, R., Roland, K., 2001. Product mix and earnings volatility at commercial banks: Evidence from a degree of total leverage model. Journal of Financial Intermediation 10, 5484.

Dingell, J., 2002. Letter to FRB and OCC re : "pay to play" practices, Jul 11. Available from www.house.gov/commerce democrats/press/1071tr179.htm.

Drakos, K., 2003. Assessing the success of reform in transition banking 10 years later: An interest margins analysis. Journal of Policy Modeling 25(3), 309-317.

European Central Bank, 2000. EU banks' income structure. Banking Supervision Committee, April. 
Gallo, J., Apilado, V., Kolari, J., 1996. Commercial bank mutual fund activities: implications for bank risk and profitability. Journal of Banking and Finance 20, 1775-1791.

Goyeau, D., Tarazi, A., 1992. Evaluation du risque de défaillance bancaire en Europe, Revue d'Economie Politique 102 (2), 249-280.

Hausman, J., 1978. Specification Tests in Econometrics. Econometrica 46, 1251-1271.

Ho, T., Saunders, A., 1981. The determinants of bank interest margins : Theory and empirical evidence. Journal of Financial and Quantitative Analysis 16(4), 581-600.

John, K., John, T.A., Saunders A., 1994. Universal banking and firm risk-taking, Journal of Banking and Finance 18(2), 307-323.

Klein, M., 1971. A theory of the banking firm. Journal of Money, Credit and Banking 3(2), 205-218.

Kwan, S., 1998. Securities activities by commercial banking firms' section 20 subsidiaries: risk, return and diversification benefits. Economic Research, Federal Reserve Bank of San Francisco.

Kwan, S., Laderman, E., 1999. On the portfolio effects of financial convergence: a review of the literature. Federal Reserve Bank of San Francisco, Economic Review 2, 18- 31.

Kwast, M., 1989. The impact of underwriting and dealing on bank returns and risks. Journal of Banking and Finance 13, 101-125.

Laderman, E., 1999. The potential diversification and failure reduction benefits of bank expansion into nonbanking activities. Economic Research, Federal Reserve Bank of San Francisco.

Lown, C., Osler, C., Strahan, P., Sufi, A., 2000. The changing landscape of the financial service industry: what lies ahead? Economic Policy Review, Federal Reserve Bank of New York. October, 39-54.

Maudos, J., De Guevara, J.F., 2004. Factors explaining the interest margin in the banking sectors of the European Union. Journal of Banking and Finance 28, 2259-2281.

Merton R.C., 1977. On the pricing of contingent claims and the Modigliani-Miller theorem. Journal of Financial Economics (5), 241-249.

Monti, M, 1972. Deposit, credit and interest rate determination under alternative bank objective functions. In: Karl Shell and Giorgio P. Szego, eds., Mathematical methods in investment and finance, North-Holland, Amsterdam, 430-454.

Nys, E., 2003. Service provision and bank interest margins: an adverse selection approach and risk implications for E.U. banks. Joint Ph-D thesis in Economics, University of Birmingham and University of Limoges. 
Puri, M., 1996. Conflicts of interest, intermediation, and the pricing of underwritten securities. Mimeo, Graduate School of Business, Stanford University, Mars.

Rajan, R., 1991. Conflict of interest and the separation of commercial and investment banking. Working Paper, University of Chicago.

Saunder, A., Walter, I., 1994. Universal banking in the United States: What could we gain? What could we lose? New York: Oxford University Press.

Saunders, A., Schumacher, L., 2000. The determinants of bank interest margins: An international study. Journal of International Money and Finance 19(6), 813-832.

Smith, R., Staikouras, C., Wood, G., 2003. Non-interest income and total income stability.Working Paper $n^{\circ} 198-$ Bank of England.

Stiroh, K., 2004. Diversification in banking: Is non-interest income the answer? Journal of Money, Credit and Banking 36(5), 853-882.

Stiroh, K., Rumble, A., 2006. The dark side of diversification: The case of US financial holding companies. Journal of Banking and Finance, forthcoming.

Wong, K.P., 1997. On the determinants of bank interest margins under credit and interest rate risks. Journal of Banking and Finance 21(2), 251-271. 
Appendix

Table A1. Distribution of banks by country

\begin{tabular}{lcc}
\hline \hline & $\begin{array}{c}\text { Non listed and } \\
\text { listed banks }\end{array}$ & Listed banks \\
\hline Austria & 32 & 4 \\
Belgium & 22 & 1 \\
Denmark & 43 & 33 \\
France & 161 & 23 \\
Germany & 198 & 16 \\
Greece & 7 & 9 \\
Italy & 152 & 26 \\
Netherlands & 31 & 1 \\
Norway & 15 & 15 \\
Portugal & 17 & 3 \\
Spain & 59 & 12 \\
Sweden & 6 & 3 \\
Switzerland & 111 & 6 \\
United Kingdom & 97 & $\mathbf{1 5 6}$ \\
\hline & $\mathbf{9 5 1}$ & \\
\hline
\end{tabular}


Table A2. Rank correlation test: product diversification and level of risk and insolvency measures for European banks (1996-2002)

\begin{tabular}{|c|c|c|c|c|c|c|c|c|c|}
\hline & \multicolumn{5}{|c|}{ Risk Measures } & \multicolumn{4}{|c|}{ Insolvency risk measures } \\
\hline & SDROA & SDROE & CVROA & CVROE & LLP & $\mathrm{ADZ}$ & ADZP & ADZP1 & ADZP2 \\
\hline \multicolumn{10}{|l|}{ NNII } \\
\hline \% Rank Cor. & 29.28 & 28.43 & 10.47 & 9.45 & 2.87 & 655.9 & -27.28 & -15.59 & -27.95 \\
\hline Spearman & & & & & & & & & \\
\hline Stat. & 9 & 8.74 & 3.22 & 2.91 & 0.86 & -201 & -8.39 & -4.80 & -8.60 \\
\hline $\begin{array}{l}\text { Significance } \\
\text { level }(\%)\end{array}$ & $0.00 * * *$ & $0.00 * * *$ & $0.13 * * *$ & $0.36 * * *$ & 39.08 & $0.00 * * *$ & $0.00 * * *$ & $0.00 * * *$ & $0.00 * * *$ \\
\hline \multicolumn{10}{|l|}{$C O M$} \\
\hline \% Rank Cor. & 22.25 & 18.57 & 7.12 & 6.84 & 1.80 & -804 & -16.38 & -7.85 & -17.01 \\
\hline Spearman & & & & & & & & & \\
\hline Stat. & 6.81 & 5.69 & 2.18 & 2.09 & 0.54 & -247 & -5.01 & -2.40 & -5.21 \\
\hline $\begin{array}{l}\text { Significance } \\
\text { level }(\%)\end{array}$ & $0.00 * * *$ & $0.00 * * *$ & $2.93 * *$ & $3.62 * *$ & 59.05 & $0.000 * * *$ & $0.00 * * *$ & $1.63 * *$ & $0.00 * * *$ \\
\hline \multicolumn{10}{|l|}{$T R A D$} \\
\hline \% Rank Cor. & 17.69 & 18.97 & 9.93 & 9.57 & 6.82 & -551 & -17.78 & -13.07 & -17.73 \\
\hline Spearman & & & & & & & & & \\
\hline & 4.71 & 5.05 & 2.64 & 2.55 & 1.77 & -168.7 & -4.73 & -3.48 & -4.72 \\
\hline $\begin{array}{l}\text { Significance } \\
\text { level }(\%)\end{array}$ & $0.00 * * *$ & $0.00 * * *$ & $0.82 * * *$ & $1.08 * *$ & $7.72 *$ & $0.000 * * *$ & $0.00 * * *$ & $0.05 * * *$ & $0.00 * * *$ \\
\hline \multicolumn{10}{|c|}{$\begin{array}{l}\text { Variable definitions: NNII = ratio of net non interest income to net operating income; COM = ratio of net } \\
\text { commission income to net operating income; TRAD = ratio of net trading income to net operating income; } \\
\text { SDROA = standard deviation of the return on average assets; SDROE = standard deviation of the return on } \\
\text { average equity; CVROA = coefficient of variation of the return on average assets; CVROE = coefficient of } \\
\text { variation of the return on average equity; LLP = ratio of loan loss provisions to net loans; ADZ = Z-score; } \\
A D Z P=\text { "ZP-score"; ADZP } P_{1}=\text { measure of bank portfolio risk; ADZP } P_{2}=\text { measure of leverage risk. }\end{array}$} \\
\hline
\end{tabular}


Table A3. Rank correlation test: product diversification and level of risk and insolvency market measures for European listed banks (1996-2002)

\begin{tabular}{|c|c|c|c|c|c|}
\hline & \multicolumn{3}{|c|}{ Risk Measures } & \multicolumn{2}{|c|}{ Insolvency risk measures } \\
\hline & SDRET & BETA & RSPEC & MDZ & $\mathrm{DD}$ \\
\hline \multicolumn{6}{|l|}{ NNII } \\
\hline \% Rank Cor. & 37.84 & 33.68 & 33.16 & -33.53 & -29.47 \\
\hline $\begin{array}{l}\text { Spearman Stat. } \\
\text { Significance }\end{array}$ & 4.71 & 4.19 & 4.13 & -4.17 & -3.63 \\
\hline level (\%) & $0.00 * * *$ & $0.00 * * *$ & $0.00 * * *$ & $0.00 * * *$ & $0.03 * * *$ \\
\hline \multicolumn{6}{|l|}{$C O M$} \\
\hline$\%$ Rank Cor. & 31.02 & 25.82 & 30.06 & -27.92 & -26.90 \\
\hline $\begin{array}{l}\text { Spearman Stat. } \\
\text { Significance }\end{array}$ & 3.85 & 3.20 & 3.73 & -3.47 & -3.31 \\
\hline level $(\%)$ & $0.01 * * *$ & $0.14 * * *$ & $0.02 * * *$ & $0.05 * * *$ & $0.09 * * *$ \\
\hline \multicolumn{6}{|l|}{$T R A D$} \\
\hline$\%$ Rank Cor. & 17.05 & 29.27 & 9.09 & -15.42 & -26.15 \\
\hline $\begin{array}{l}\text { Spearman Stat. } \\
\text { Significance }\end{array}$ & 1.98 & 3.40 & 1.06 & -1.79 & -3.02 \\
\hline level $(\%)$ & $4.76^{* *}$ & $0.07 * * *$ & 29.09 & $7.32 *$ & $0.26 * * *$ \\
\hline
\end{tabular}

T statistics test for the null:"Risk/Insolvency is not higher for high level of product diversification". ***, ** and * indicate significance respectively at the $1 \%, 5 \%$ and $10 \%$ levels for a unilateral test. Variable definitions: NNII = ratio of net non interest income to net operating income; COM = ratio of net commission income to net operating income; TRAD = ratio of net trading income to net operating income; SDRET = standard deviation of daily returns; BETA = market model beta; RSPEC = standard deviation of the market model residual; $M D Z=$ market data based Z-score; $D D=$ distance to default. 
Table A4. Cross section regression (OLS): impact of product diversification on net interest margin for European banks (1996)

\begin{tabular}{|c|c|c|c|c|c|c|c|c|c|c|c|}
\hline Equation & $\begin{array}{c}\mathrm{R} 3 \mathrm{M} \\
(+)\end{array}$ & $\begin{array}{c}\text { LLP } \\
(+)\end{array}$ & $\begin{array}{c}\text { LIQUIDITY } \\
(+)\end{array}$ & $\begin{array}{c}\text { EQUITY } \\
(+)\end{array}$ & $\begin{array}{c}\text { EXPENSES } \\
(+/-)\end{array}$ & $\begin{array}{c}\text { TA_R } \\
(+/-)\end{array}$ & $\begin{array}{c}\text { NNII } \\
(-)\end{array}$ & $\begin{array}{c}\text { COMSHA } \\
(-)\end{array}$ & $\begin{array}{c}\mathrm{COM} \\
(-)\end{array}$ & $\begin{array}{c}\text { TRAD } \\
(-)\end{array}$ & $\mathrm{R}^{2}$ \\
\hline \multicolumn{12}{|c|}{ Dependant variable: W_MARGIN (309 obs.) } \\
\hline$[1]$ & $\begin{array}{c}0.298 * * * \\
(9.237)\end{array}$ & $\begin{array}{c}0.074 \\
(0.813)\end{array}$ & $\begin{array}{c}-0.000 \\
(-0.170)\end{array}$ & $\begin{array}{c}-0.008 \\
(-0.486)\end{array}$ & $\begin{array}{c}0.614 * * * \\
(5.331)\end{array}$ & $\begin{array}{c}-6.537 * * * \\
(-3.174)\end{array}$ & - & - & - & - & 0.397 \\
\hline$[2]$ & $\begin{array}{c}0.178 * * * \\
(6.256)\end{array}$ & $\begin{array}{c}0.250 * * * \\
(3.554)\end{array}$ & $\begin{array}{c}0.000 \\
(0.168)\end{array}$ & $\begin{array}{c}0.001 \\
(0.056)\end{array}$ & $\begin{array}{c}0.966^{* * * *} \\
(9.359)\end{array}$ & $\begin{array}{c}-1.089 \\
(-0.629)\end{array}$ & $\begin{array}{c}-0.046 * * * \\
(-13.855)\end{array}$ & - & - & - & 0.682 \\
\hline$[3]$ & $\begin{array}{c}0.190 * * * \\
(6.279)\end{array}$ & $\begin{array}{c}0.234^{* * *} \\
(3.441)\end{array}$ & $\begin{array}{c}0.000 \\
(0.056)\end{array}$ & $\begin{array}{c}0.007 \\
(0.637)\end{array}$ & $\begin{array}{c}0.913 * * * \\
(8.891)\end{array}$ & $\begin{array}{c}-0.958 \\
(-0.562)\end{array}$ & $\begin{array}{c}-0.047 * * * \\
(-14.031)\end{array}$ & $\begin{array}{c}0.329 * * * \\
(4.739)\end{array}$ & - & - & 0.700 \\
\hline$[4]$ & $\begin{array}{c}0.160 * * * \\
(4.909)\end{array}$ & $\begin{array}{c}0.245^{* * *} * \\
(3.447)\end{array}$ & $\begin{array}{c}-0.000 \\
(-0.180)\end{array}$ & $\begin{array}{c}-0.001 \\
(-0.069)\end{array}$ & $\begin{array}{c}0.977 * * * \\
(8.336)\end{array}$ & $\begin{array}{l}-3.169 \\
(-1.637)\end{array}$ & - & - & $\begin{array}{c}-0.049 * * * \\
(-10.079)\end{array}$ & $\begin{array}{c}-0.035 * * * \\
(-4.434)\end{array}$ & 0.667 \\
\hline \multicolumn{12}{|c|}{ Dependant variable: $N \_$MARGIN (309 obs.) } \\
\hline$\left[1^{\prime}\right]$ & $\begin{array}{c}-0.097 \\
(-1.490)\end{array}$ & $\begin{array}{c}0.512^{* *} \\
(2.186)\end{array}$ & $\begin{array}{c}0.000 \\
(0.026)\end{array}$ & $\begin{array}{l}0.067^{* *} \\
(2.272)\end{array}$ & $\begin{array}{l}0.564 * * \\
(2.415)\end{array}$ & $\begin{array}{c}-4.535 \\
(-0.775)\end{array}$ & & & & & 0.127 \\
\hline$\left[2^{\prime}\right]$ & $\begin{array}{c}-0.084 \\
(-1.347)\end{array}$ & $\begin{array}{c}0.524 * * \\
(2.299)\end{array}$ & $\begin{array}{c}0.000 \\
(0.182)\end{array}$ & $\begin{array}{l}0.059^{*} \\
(1.932)\end{array}$ & $\begin{array}{l}0.477^{*} \\
(1.837)\end{array}$ & $\begin{array}{c}-6.393 \\
(-1.043)\end{array}$ & $\begin{array}{c}-0.012 \\
(-1.126)\end{array}$ & & & & 0.129 \\
\hline [3'] & $\begin{array}{c}-0.093 \\
(-1.473)\end{array}$ & $\begin{array}{c}0.521 * * \\
(2.281)\end{array}$ & $\begin{array}{c}0.000 \\
(0.141)\end{array}$ & $\begin{array}{l}0.059^{*} \\
(1.914)\end{array}$ & $\begin{array}{l}0.480^{*} \\
(1.858)\end{array}$ & $\begin{array}{c}-6.365 \\
(-1.028)\end{array}$ & $\begin{array}{c}-0.012 \\
(-1.091)\end{array}$ & $\begin{array}{c}-0.114 \\
(-0.478)\end{array}$ & & & 0.128 \\
\hline$\left[4^{\prime}\right]$ & $\begin{array}{c}0.170 * * \\
(2.285)\end{array}$ & $\begin{array}{c}0.587 * * \\
(2.152)\end{array}$ & $\begin{array}{c}-0.000 \\
(-0.463)\end{array}$ & $\begin{array}{c}0.092 * * * \\
(2.802)\end{array}$ & $\begin{array}{l}0.503^{*} \\
(1.670)\end{array}$ & $\begin{array}{c}-1.326 \\
(-0.313)\end{array}$ & & & $\begin{array}{c}0.012 \\
(0.818)\end{array}$ & $\begin{array}{c}0.054 \\
(0.999)\end{array}$ & 0.212 \\
\hline
\end{tabular}

Variable definitions: W MARGIN = net interest income/total earning assets; N_MARGIN = (interest income from loans/net loans) - interest expenses/total liabiities ; LIQUIDITY ${ }_{i t}=$ net loans/deposits; TA $R_{i t}=$ total assets for bank $i$ divided by the sum of the total asset of the banking system; $R 3 M_{i t}=$ the three months interbank rate; LLP

$=$ loan loss provisions/net loans for bank $i$ at time $t$; $E Q U I T Y_{i t}=$ equity/total assets for bank $i$ at time $t$; EXPENSES ${ }_{\text {it }}=$ personnel expenses/total assets for bank $i$ at time $t$; $N_{N I I}=$ net non-interest income/ total net operating income for bank $i$ at time $t$; $C_{\text {it }}=$ net commission and fee income/ total net operating income for bank $i$ at time $t$;

$T R A D_{i t}=$ net trading income/ total net operating income for bank i at time ; COMSHA $_{\text {it }}=$ net commission and fee income/ net non-interest income. 
Table A5. Cross section regression (OLS): impact of product diversification on risk premium for European banks (1996)

\begin{tabular}{|c|c|c|c|c|c|c|c|c|c|c|}
\hline Equation & $\begin{array}{c}\text { VR3M } \\
(+)\end{array}$ & $\begin{array}{l}\text { LLP } \\
(+)\end{array}$ & $\begin{array}{c}\text { EQUITY } \\
(+)\end{array}$ & $\begin{array}{c}\text { EXPENSES } \\
(+/-)\end{array}$ & $\begin{array}{c}\text { TA_R } \\
(+/-)\end{array}$ & $\begin{array}{l}\text { NNII } \\
(-)\end{array}$ & $\begin{array}{c}\text { COMSHA } \\
(-)\end{array}$ & $\begin{array}{c}\mathrm{COM} \\
(-)\end{array}$ & $\begin{array}{c}\text { TRAD } \\
(-)\end{array}$ & $\mathrm{R}^{2}$ \\
\hline \multicolumn{11}{|c|}{ Dependant variable: W_SPREAD (309 obs.) } \\
\hline [5] & $\begin{array}{c}1.605 * * * \\
(4.578)\end{array}$ & $\begin{array}{c}0.103 \\
(0.884)\end{array}$ & $\begin{array}{c}-0.041 \\
(-1.114)\end{array}$ & $\begin{array}{l}0.392 * \\
(1.671)\end{array}$ & $\begin{array}{c}-12.773 * * \\
(-2.489)\end{array}$ & - & - & - & - & 0.116 \\
\hline$[6]$ & $\begin{array}{c}0.376 \\
(0.939)\end{array}$ & $\begin{array}{c}0.359 * * * \\
(3.156)\end{array}$ & $\begin{array}{c}-0.021 \\
(-0.750)\end{array}$ & $\begin{array}{c}0.863 * * * \\
(3.698)\end{array}$ & $\begin{array}{c}0.131 \\
(0.041)\end{array}$ & $\begin{array}{c}-0.056 * * * \\
(-6.314)\end{array}$ & - & - & - & 0.362 \\
\hline [7] & $\begin{array}{c}0.502 \\
(1.408)\end{array}$ & $\begin{array}{c}0.313 * * * \\
(3.059)\end{array}$ & $\begin{array}{c}-0.007 \\
(-0.329)\end{array}$ & $\begin{array}{c}0.745 * * * \\
(4.708)\end{array}$ & $\begin{array}{c}-0.065 \\
(-0.022)\end{array}$ & $\begin{array}{c}-0.058 * * * \\
(-7.407)\end{array}$ & $\begin{array}{c}0.791 * * \\
(2.580)\end{array}$ & - & - & 0.425 \\
\hline [8] & $\begin{array}{c}0.174 \\
(0.401)\end{array}$ & $\begin{array}{c}0.335^{* * *} * \\
(2.982)\end{array}$ & $\begin{array}{c}-0.027 \\
(-0.852)\end{array}$ & $\begin{array}{c}0.869 * * * \\
(3.519)\end{array}$ & $\begin{array}{l}-3.259 \\
(-0.957)\end{array}$ & & - & $\begin{array}{c}-0.062 * * * \\
(-6.444)\end{array}$ & $\begin{array}{c}-0.019 \\
(-1.248)\end{array}$ & 0.309 \\
\hline \multicolumn{11}{|c|}{ Dependant variable: N_SPREAD (309 obs.) } \\
\hline [5'] & $\begin{array}{c}-0.527 \\
(-1.403)\end{array}$ & $\begin{array}{c}0.442 * * \\
(2.101)\end{array}$ & $\begin{array}{c}0.081 * * \\
(2.593)\end{array}$ & $\begin{array}{c}0.464 * * \\
(2.489)\end{array}$ & $\begin{array}{l}-9.409 * \\
(-1.716)\end{array}$ & - & - & - & - & 0.120 \\
\hline [6'] & $\begin{array}{c}-0.511 \\
(-1.352)\end{array}$ & $\begin{array}{c}0.455^{* *} \\
(2.147)\end{array}$ & $\begin{array}{c}0.078 * * \\
(2.460)\end{array}$ & $\begin{array}{c}0.428 * * \\
(2.084)\end{array}$ & $\begin{array}{c}-10.195^{*} \\
(-1.697)\end{array}$ & $\begin{array}{c}0.004 \\
(0.416)\end{array}$ & - & - & - & 0.119 \\
\hline [7'] & $\begin{array}{c}-0.515 \\
(-1.342)\end{array}$ & $\begin{array}{c}0.454^{* *} \\
(2.141)\end{array}$ & $\begin{array}{c}0.078 * * \\
(2.459)\end{array}$ & $\begin{array}{c}0.427 * * \\
(2.061)\end{array}$ & $\begin{array}{c}-10.192^{*} \\
(-1.696)\end{array}$ & $\begin{array}{c}0.004 \\
(0.398)\end{array}$ & $\begin{array}{c}0.007 \\
(0.030)\end{array}$ & - & - & 0.118 \\
\hline [8'] & $\begin{array}{c}1.574 * * * \\
(3.169)\end{array}$ & $\begin{array}{l}0.428 * \\
(1.741) \\
\end{array}$ & $\begin{array}{c}0.104 * * * \\
(3.099)\end{array}$ & $\begin{array}{l}0.426^{*} \\
(1.830) \\
\end{array}$ & $\begin{array}{c}-6.333 \\
(-1.067) \\
\end{array}$ & - & - & $\begin{array}{c}0.005 \\
(0.354) \\
\end{array}$ & $\begin{array}{c}0.051 * * * \\
(3.499) \\
\end{array}$ & 0.206 \\
\hline
\end{tabular}

Variable definitions: W SPREAD = the ratio of net interest income to total earning assets - the 10 year government bond rate; $N$ SPREAD = lending rate determined as the ratio of interest from loans to net loans - the 10 year government bond rate; TA_ $R_{i t}=$ total assets for bank $i$ divided by the sum of the total asset of the banking system; $V R 3 M_{j t}=$ volatility of the three months interbank rate (standard deviation computed with daily data) for country $j ;$ LLP it $=$ loan loss provisions/net loans for bank $i$ at time $t ;$

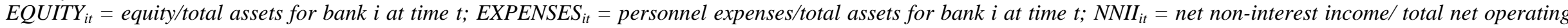
income for bank $i$ at time $t$; $C O M_{i t}=$ net commission and fee income/ total net operating income for bank $i$ at time $t$; TRAD for bank i at time $t$; COMSHA ${ }_{\text {it }}=$ net commission and fee income/ net non-interest income. 
Table A6. Cross section regression (OLS): impact of product diversification on net interest margin for European banks (2002)

\begin{tabular}{|c|c|c|c|c|c|c|c|c|c|c|c|}
\hline Equation & $\begin{array}{c}\mathrm{R} 3 \mathrm{M} \\
(+)\end{array}$ & $\begin{array}{c}\text { LLP } \\
(+)\end{array}$ & $\begin{array}{c}\text { LIQUIDITY } \\
(+)\end{array}$ & $\begin{array}{c}\text { EQUITY } \\
(+)\end{array}$ & $\begin{array}{c}\text { EXPENSES } \\
(+/-)\end{array}$ & $\begin{array}{c}\text { TA_R } \\
(+/-)\end{array}$ & $\begin{array}{c}\text { NNII } \\
(-)\end{array}$ & $\begin{array}{c}\text { COMSHA } \\
(-)\end{array}$ & $\begin{array}{c}\mathrm{COM} \\
(-)\end{array}$ & $\begin{array}{c}\text { TRAD } \\
(-)\end{array}$ & $\mathrm{R}^{2}$ \\
\hline \multicolumn{12}{|c|}{ Dependant variable: W_MARGIN (299 obs.) } \\
\hline$[1]$ & $\begin{array}{c}0.266^{* * * *} \\
(7.543)\end{array}$ & $\begin{array}{l}0.160^{*} \\
(1.774)\end{array}$ & $\begin{array}{c}0.000 \\
(0.045)\end{array}$ & $\begin{array}{c}0.011 \\
(1.004)\end{array}$ & $\begin{array}{l}0.189^{*} \\
(1.897)\end{array}$ & $\begin{array}{c}-5.440 * * * \\
(-4.518)\end{array}$ & - & - & - & - & 0.186 \\
\hline$[2]$ & $\begin{array}{c}0.211 * * * \\
(5.914)\end{array}$ & $\begin{array}{l}0.147 * * \\
(2.347)\end{array}$ & $\begin{array}{c}-0.000 \\
(-0.100)\end{array}$ & $\begin{array}{c}0.009 \\
(0.883)\end{array}$ & $\begin{array}{c}0.466^{* * *} \\
(3.776)\end{array}$ & $\begin{array}{c}-2.897 * * * \\
(-3.124)\end{array}$ & $\begin{array}{c}-0.029 * * * \\
(-12.324)\end{array}$ & - & - & - & 0.471 \\
\hline$[3]$ & $\begin{array}{c}0.214 * * * \\
(6.192)\end{array}$ & $\begin{array}{c}0.147 * * \\
(2.341)\end{array}$ & $\begin{array}{c}-0.000 \\
(-0.116)\end{array}$ & $\begin{array}{c}0.009 \\
(0.941)\end{array}$ & $\begin{array}{c}0.469 * * * \\
(3.761)\end{array}$ & $\begin{array}{c}-2.984 * * * \\
(-3.156)\end{array}$ & $\begin{array}{c}-0.030 * * * \\
(-10.840)\end{array}$ & $\begin{array}{c}-0.073 \\
(-0.654)\end{array}$ & - & - & 0.473 \\
\hline$[4]$ & $\begin{array}{c}0.205^{* * *} \\
(5.948)\end{array}$ & $\begin{array}{l}0.142 * * \\
(2.329)\end{array}$ & $\begin{array}{c}-0.000 \\
(-0.229)\end{array}$ & $\begin{array}{c}0.012 \\
(1.232) \\
\end{array}$ & $\begin{array}{c}0.468 * * * \\
(3.477)\end{array}$ & $\begin{array}{c}-3.557 * * * \\
(-4.046)\end{array}$ & - & - & $\begin{array}{c}-0.030 * * * \\
(-7.254)\end{array}$ & $\begin{array}{c}-0.033 * * * \\
(-9.666)\end{array}$ & 0.493 \\
\hline \multicolumn{12}{|c|}{ Dependant variable: $N \_M A R G I N$ (299 obs.) } \\
\hline$\left[1^{\prime}\right]$ & $\begin{array}{c}-0.071 \\
(-0.690)\end{array}$ & $\begin{array}{c}0.924 * * * \\
(5.508)\end{array}$ & $\begin{array}{c}0.000 \\
(0.608)\end{array}$ & $\begin{array}{c}0.007 \\
(0.375)\end{array}$ & $\begin{array}{l}0.312^{* *} \\
(2.412)\end{array}$ & $\begin{array}{c}-8.154 * * * \\
(-3.972)\end{array}$ & - & - & - & - & 0.127 \\
\hline$\left[2^{\prime}\right]$ & $\begin{array}{c}-0.065 \\
(-0.635)\end{array}$ & $\begin{array}{c}0.904 * * * \\
(5.334)\end{array}$ & $\begin{array}{c}0.000 \\
(0.700)\end{array}$ & $\begin{array}{c}0.004 \\
(0.214)\end{array}$ & $\begin{array}{l}0.277^{*} \\
(1.722)\end{array}$ & $\begin{array}{c}-8.545 * * * \\
(-3.832)\end{array}$ & $\begin{array}{c}-0.004 \\
(-0.452)\end{array}$ & - & - & - & 0.122 \\
\hline [3'] & $\begin{array}{c}-0.057 \\
(-0.556)\end{array}$ & $\begin{array}{c}0.894 * * * \\
(5.277)\end{array}$ & $\begin{array}{l}-0.000 \\
(-0.226)\end{array}$ & $\begin{array}{c}0.004 \\
(0.229)\end{array}$ & $\begin{array}{l}0.285^{*} \\
(1.751)\end{array}$ & $\begin{array}{c}-8.682 * * * \\
(-3.846)\end{array}$ & $\begin{array}{c}-0.004 \\
(-0.410)\end{array}$ & $\begin{array}{c}-0.216 \\
(-1.097)\end{array}$ & - & - & 0.123 \\
\hline$\left[4^{\prime}\right]$ & $\begin{array}{c}-0.019 \\
(-0.194)\end{array}$ & $\begin{array}{c}0.995 * * * \\
(4.537)\end{array}$ & $\begin{array}{l}-0.000 \\
(-1.436)\end{array}$ & $\begin{array}{c}0.022 \\
(1.128)\end{array}$ & $\begin{array}{c}0.506^{* *} \\
(2.734)\end{array}$ & $\begin{array}{c}-3.397 * * \\
(-2.103)\end{array}$ & - & - & $\begin{array}{c}-0.024 * * \\
(-2.509)\end{array}$ & $\begin{array}{c}0.000 \\
(0.011)\end{array}$ & 0.215 \\
\hline
\end{tabular}

Variable definitions: W MARGIN = net interest income/total earning assets; N_MARGIN = (interest income from loans/net loans) - interest expenses/total liabiities ; LIQUIDITY ${ }_{i t}=$ net loans/deposits; TA $R_{i t}=$ total assets for bank $i$ divided by the sum of the total asset of the banking system; $R 3 M_{i t}=$ the three months interbank rate; LLP

$=$ loan loss provisions/net loans for bank $i$ at time $t$; $E Q U I T Y_{i t}=$ equity/total assets for bank $i$ at time $t$; EXPENSES ${ }_{\text {it }}=$ personnel expenses/total assets for bank $i$ at time $t$; $N_{N I I}=$ net non-interest income/ total net operating income for bank $i$ at time $t$; $C_{\text {it }}=$ net commission and fee income/ total net operating income for bank $i$ at time $t$;

$T R A D_{i t}=$ net trading income/ total net operating income for bank i at time ; COMSHA $_{\text {it }}=$ net commission and fee income/ net non-interest income. 
Table A7. Cross section regression (OLS): impact of product diversification on risk premium for European banks (2002)

\begin{tabular}{|c|c|c|c|c|c|c|c|c|c|c|}
\hline Equation & $\begin{array}{c}\text { VR3M } \\
(+)\end{array}$ & $\begin{array}{l}\text { LLP } \\
(+)\end{array}$ & $\begin{array}{c}\text { EQUITY } \\
(+)\end{array}$ & $\begin{array}{c}\text { EXPENSES } \\
(+/-)\end{array}$ & $\begin{array}{c}\text { TA_R } \\
(+/-)\end{array}$ & $\begin{array}{l}\text { NNII } \\
(-)\end{array}$ & $\begin{array}{c}\text { COMSHA } \\
(-)\end{array}$ & $\begin{array}{c}\mathrm{COM} \\
(-)\end{array}$ & $\begin{array}{l}\text { TRAD } \\
(-)\end{array}$ & $\mathrm{R}^{2}$ \\
\hline \multicolumn{11}{|c|}{ Dependant variable: W_SPREAD (309 obs.) } \\
\hline [5] & $\begin{array}{c}2.712^{* * *} \\
(2.992)\end{array}$ & $\begin{array}{l}-0.023 \\
(-0.147)\end{array}$ & $\begin{array}{c}0.005 \\
(0.141)\end{array}$ & $\begin{array}{c}-0.089 \\
(-1.354)\end{array}$ & $\begin{array}{l}-1.485 \\
(-1.22)\end{array}$ & - & - & - & - & 0.054 \\
\hline$[6]$ & $\begin{array}{c}2.834 * * * \\
(3.220)\end{array}$ & $\begin{array}{c}-0.010 \\
(-0.067)\end{array}$ & $\begin{array}{c}0.011 \\
(0.258)\end{array}$ & $\begin{array}{c}-0.028 \\
(-0.147)\end{array}$ & $\begin{array}{c}-0.497 \\
(-0.388)\end{array}$ & $\begin{array}{c}-0.014 * * \\
(-2.319)\end{array}$ & - & - & - & 0.083 \\
\hline$[7]$ & $\begin{array}{c}2.928 * * * \\
(3.364)\end{array}$ & $\begin{array}{c}-0.009 \\
(-0.062)\end{array}$ & $\begin{array}{c}0.012 \\
(0.267)\end{array}$ & $\begin{array}{c}-0.016 \\
(-0.084)\end{array}$ & $\begin{array}{c}-0.628 \\
(-0.496)\end{array}$ & $\begin{array}{c}-0.015 * * \\
(-2.460)\end{array}$ & $\begin{array}{c}-0.201 \\
(-1.364)\end{array}$ & - & - & 0.089 \\
\hline$[8]$ & $\begin{array}{c}3.126^{* * *} \\
(3.621)\end{array}$ & $\begin{array}{c}0.009 \\
(0.058)\end{array}$ & $\begin{array}{c}0.017 \\
(0.462)\end{array}$ & $\begin{array}{c}-0.035 \\
(-0.577)\end{array}$ & $\begin{array}{c}-1.051 \\
(-0.856)\end{array}$ & & - & $\begin{array}{c}-0.022 * * * \\
(-3.357)\end{array}$ & $\begin{array}{c}-0.003 \\
(-0.391)\end{array}$ & 0.113 \\
\hline \multicolumn{11}{|c|}{ Dependant variable: N_SPREAD (309 obs.) } \\
\hline$\left[5^{\prime}\right]$ & $\begin{array}{c}5.061 * * * \\
(3.661)\end{array}$ & $\begin{array}{c}0.945^{* * *} \\
(6.457)\end{array}$ & $\begin{array}{c}0.004 \\
(0.249)\end{array}$ & $\begin{array}{c}0.021 \\
(0.278)\end{array}$ & $\begin{array}{c}-9.381 * * * \\
(-4.470)\end{array}$ & - & - & - & - & 0.120 \\
\hline [6’] & $\begin{array}{c}4.946 * * * \\
(3.673)\end{array}$ & $\begin{array}{c}0.946^{* * *} \\
(6.238)\end{array}$ & $\begin{array}{c}0.003 \\
(0.182)\end{array}$ & $\begin{array}{c}-0.005 \\
(-0.033)\end{array}$ & $\begin{array}{c}-9.504 * * * \\
(-4.222)\end{array}$ & $\begin{array}{c}0.005 \\
(0.540)\end{array}$ & - & - & - & 0.119 \\
\hline [7'] & $\begin{array}{c}5.210 * * * \\
(3.874)\end{array}$ & $\begin{array}{c}0.929 * * * \\
(6.166)\end{array}$ & $\begin{array}{c}0.003 \\
(0.147)\end{array}$ & $\begin{array}{c}0.014 \\
(0.086)\end{array}$ & $\begin{array}{c}-9.812 * * * \\
(-4.298)\end{array}$ & $\begin{array}{c}0.004 \\
(0.400)\end{array}$ & $\begin{array}{c}-0.573 * * * \\
(-3.458)\end{array}$ & - & - & 0.118 \\
\hline [8'] & $\begin{array}{c}5.977 * * * \\
(4.707) \\
\end{array}$ & $\begin{array}{c}0.875^{* * * *} \\
(4.704)\end{array}$ & $\begin{array}{c}0.032 \\
(1.565) \\
\end{array}$ & $\begin{array}{c}0.027 \\
(0.371) \\
\end{array}$ & $\begin{array}{c}-3.313 * * \\
(-2.281) \\
\end{array}$ & - & - & $\begin{array}{c}0.007 \\
(0.691) \\
\end{array}$ & $\begin{array}{c}-0.014 \\
(-1.139) \\
\end{array}$ & 0.206 \\
\hline
\end{tabular}

Variable definitions: W SPREAD = the ratio of net interest income to total earning assets - the 10 year government bond rate; $N$ SPREAD = lending rate determined as the ratio of interest from loans to net loans - the 10 year government bond rate; TA_ $R_{i t}=$ total assets for bank $i$ divided by the sum of the total asset of the banking system; $V R 3 M_{i t}=$ volatility of the three months interbank rate (standard deviation computed with daily data) for country $j ;$ LLP

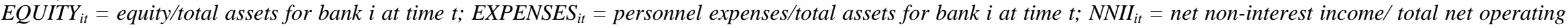
income for bank $i$ at time $t$; $C O M_{i t}=$ net commission and fee income/ total net operating income for bank $i$ at time $t$; TRA $D_{i t}=n e t$ trading income/ total net operating income for bank i at time $t$; COMSHA ${ }_{i t}=$ net commission and fee income/ net non-interest income. 
